\title{
Function, essentiality, and expression of cytochrome P450 enzymes and their cognate redox partners in Mycobacterium tuberculosis: are they drug targets?
}

\author{
Sandra Ortega Ugalde ${ }^{1} \cdot$ Maikel Boot $^{2} \cdot \operatorname{Jan}$ N. M. Commandeur ${ }^{1} \cdot$ Paul Jennings $^{1} \cdot$ Wilbert Bitter $^{3} \cdot$ J. Chris Vos $^{1}$
}

Received: 30 November 2018 / Revised: 8 February 2019 / Accepted: 10 February 2019 / Published online: 27 February 2019

(C) The Author(s) 2019

\begin{abstract}
This review covers the current knowledge of the cytochrome P450 enzymes (CYPs) of the human pathogen Mycobacterium tuberculosis (Mtb) and their endogenous redox partners, focusing on their biological function, expression, regulation, involvement in antibiotic resistance, and suitability for exploitation as antitubercular targets. The Mtb genome encodes twenty CYPs and nine associated redox partners required for CYP catalytic activity. Transposon insertion mutagenesis studies have established the (conditional) essentiality of several of these enzymes for in vitro growth and host infection. Biochemical characterization of a handful of Mtb CYPs has revealed that they have specific physiological functions in bacterial virulence and persistence in the host. Analysis of the transcriptional response of Mtb CYPs and redox partners to external insults and to first-line antibiotics used to treat tuberculosis showed a diverse expression landscape, suggesting for some enzymes a potential role in drug resistance. Combining the knowledge about the physiological roles and expression profiles indicates that, at least five Mtb CYPs, CYP121A1, CYP125A1, CYP139A1, CYP142A1, and CYP143A1, as well as two ferredoxins, FdxA and FdxC, can be considered promising novel therapeutic targets.
\end{abstract}

Keywords Cytochrome P450 $\cdot$ Mycobacterium tuberculosis $\cdot$ Redox partners $\cdot$ Essentiality $\cdot$ Stress response $\cdot$ Antibiotic exposure response

\section{Introduction}

\section{Tuberculosis}

Tuberculosis (TB) is caused by the human pathogen Mycobacterium tuberculosis (Mtb). In 2017, 10 million new TB cases were reported worldwide and 1.3 million people died from TB infection, making it the deadliest infectious disease known to humankind (World Health Organization

Sandra Ortega Ugalde

s.ortegaugalde@vu.nl

1 Division of Molecular Toxicology, Amsterdam Institute for Molecules Medicines and Systems (AIMMS), Faculty of Sciences, Vrije Universiteit, De Boelelaan 1108, 1081

HZ Amsterdam, The Netherlands

2 Department of Microbial Pathogenesis, Yale University School of Medicine, New Haven, CT, USA

3 Section of Molecular Microbiology, AIMMS, Faculty of Sciences, Vrije Universiteit, Amsterdam, The Netherlands
2018). The emergence of Mtb strains resistant to the firstline anti-TB agents, i.e., ethambutol, isoniazid, pyrazinamide, and rifampicin, as well as the fatal synergy with HIV, has prompted the development and FDA approval of new drugs for TB, such as bedaquiline and delamanid. In this context, the determination of the complete genome sequence of $\mathrm{Mtb}$ and development of genetic tools have been instrumental in uncovering the biology of this unconventional pathogen and the identification of novel drug targets (Cole et al. 1998).

The mycobacterial genome encodes a large variety of enzymes involved in lipid biosynthesis and metabolism, reflecting its elaborate capability to use lipid metabolism for both energy homeostasis and synthesis of many different components of the complex cell envelope (Gazaei 2018). This unusual cell envelope is critical for Mtb's persistence, providing not only mechanical strength and protection to hostile environments but also a barrier to the entry of harmful compounds (Nikaido and Jarlier 1991; Chiaradia et al. 2017). Fortunately, because the mycobacterial cell envelope contains many unique structures, the enzymes involved in its biogenesis provide us with many Mtb-specific drug targets and thus 
the possibility to develop compounds that are highly specific to mycobacteria. Recent examples include the benzothiazinones that block arabinogalactan biosynthesis and delamanid that interferes with mycolic acid biosynthesis (Riccardi and Pasca 2014).

Genome mapping revealed that Mtb encodes a high number of cytochrome P450 enzymes (CYPs or P450s). CYPs are haem-containing monooxygenase enzymes involved in lipid and steroid metabolism in eukaryotes. In fungi, several CYPs are already validated drug targets. An example is CYP51, the fungal sterol-14 $\alpha$-demethylase involved in the biosynthesis of membrane sterols. CYP51 can be inhibited by several azole-compounds (Warrilow et al. 2013). The use of anti-fungal azoles to inhibit CYP51 has also been proposed as treatment for parasitic infections, such as Chagas disease and the African sleeping sickness (Lepesheva et al. 2008; Chen et al. 2010). A homolog of CYP51 is also encoded in Mtb genome, cyp51b1, highlighting its potential use as a drug target. Interestingly, CYP-inhibiting azole drugs have potent anti-mycobacterial activity and econazole reduced bacterial burden by $90 \%$ in the lungs and spleen of mice infected with Mtb (Guardiola-Diaz et al. 2001; Ahmad et al. 2006a, b; McLean et al. 2006a). However, it remains unclear whether the growth inhibition was due to inhibition of one or more Mtb CYPs by econazole (Ahmad et al. 2006b).

In light of the potential role of CYPs in physiology and pathology, as well as their proven efficiency as therapeutic targets in mycobacteria, in-depth understanding of the physiological function and biochemical characterization of these enzymes is a priority. In this review, we update the current knowledge on the essentiality and physiological function of Mtb CYPs and their cognate redox partners, which has been reviewed before, adding new sections on CYP139A1 and CYP143A1 (McLean et al. 2006a, 2007, 2010; McLean and Munro 2008; Ouellet et al. 2010a; Ortiz de Montellano 2018). Furthermore, we aim to understand the regulatory network governing their expression profiles in response to various external stimuli Mtb encounters during host infection, such as nutrient depletion, hypoxia, and antibiotic exposure. We believe that the information in this mini-review will aid in assessing whether specific Mtb CYPs and redox partners are suitable candidates for the development of novel anti-TB drugs.

\section{The CYP family and cognate redox partners in Mtb}

The $4.4 \mathrm{Mb}$ genome of Mtb H37Rv contains twenty CYP genes (Cole et al. 1998). This is a relatively high number for prokaryotes, as most sequenced bacterial genomes generally contain a small number of $C Y P$ genes. The high abundance of CYP genes is a general characteristic of mycobacteria exemplified by Mycobacterium rhodesiae NBB3 (70), Mycobacterium avium 104 (48), Mycobacterium marinum (47), Mycobacterium smegmatis MC2 (42), and Mycobacterium abscessus 47J26s/103 (25) as compiled by Parvez et al. (2016). In contrast, Mycobacterium leprae has lost all but one functional CYP protein, encoded by $M L 2088 \mathrm{c}$ (37\% identity to Mtb CYP140A1). However, this is consistent with the overall reduction in genome size in M. leprae. Deciphering the physiological function of CYPs is usually performed through a combination of homology modeling/ mapping, generation of single gene knockouts and/or biochemical characterization of the protein. Yet, despite the high abundance of CYP genes in mycobacteria, phylogenetic analysis has shown that Mtb CYPs exhibit relatively low evolutionary relationships with other species, with many bacterial species (like Escherichia coli) lacking CYPs altogether. CYP121A1, CYP128A1, CYP135, and CYP141A1 are predominantly found in mycobacteria belonging to the MTBC (Ouellet et al. 2010a). In addition, the overall homology between the $20 \mathrm{Mtb}$ CYPs is rather low, with a maximum homology of 40\% between CYP135A1 and CYP135B1 in Mtb.

The catalytic activity of CYPs is dependent on their redox partners (McLean et al. 2005). CYPs are classified based on the type of redox systems they pair with. All Mtb CYPs belong to class I, meaning their catalytic activity is dependent on a $\mathrm{NAD}(\mathrm{P}) \mathrm{H}$-ferredoxin-reductase (FNR) and a ferredoxin (Fd). Mtb encodes five ferredoxins genes, Fdx $(R v 0763 c), \mathrm{FdxA}(R v 2007 c), \mathrm{FdxC}$ (Rv1177), FdxD (Rv3503c), and Rv1786; two FNRs namely FdrA (Rv0688) and FprA (Rv3106); and two FdFNR fusions, FdxB (Rv3554) and FprB (Rv0886). Fdx, $\mathrm{FdxD}$, and FdxE share a common Cys- $X_{2}-\underline{X}-X_{2}$-Cys- $X_{n}{ }^{-}$ Cys-Pro iron-sulfur cluster-binding motif, where $X$ is any amino acid and $X_{n}$ indicates a number of flexible amino acids. This motif is consistent with a [3Fe-4S] cluster which is conserved on ferredoxins from other bacteria (Trower et al. 1993; Duff et al. 1996; Green et al. 2003; Sevrioukova 2005; Lu et al. 2017; Child et al. 2018). On the other hand, FdxA and FdxC resemble FdxA from M. smegmatis $(M s F d)$, a $7 \mathrm{Fe}$-ferredoxin that contains both a $[3 \mathrm{Fe}-4 \mathrm{~S}]$ and a $[4 \mathrm{Fe}-4 \mathrm{~S}]$ iron-cluster combined in a single protein (Ricagno et al. 2007; Ortega Ugalde et al. 2018a). The overall sequence identity between the [3Fe4S] cluster-containing Mtb ferredoxins Fdx, FdxD, and FdxE is approximately $30 \%$, whereas FprA displays approximately $40 \%$ sequence identity to the mammalian adrenoxin reductase (AdR) (Ricagno et al. 2007; Fischer et al. 2002; Ortega Ugalde et al. 2018a).

\section{Mtb CYPs and cognate redox partners essentiality}

Important information on the essentiality of certain CYPs for bacterial adaptation, growth, survival, and virulence can be 
obtained from transposon site hybridization (TraSH) studies. To date, several of these studies have been performed and a summary of the results for Mtb CYPs and their cognate redox partners is presented in Table 1.

The results of these studies confirm the non-essentiality of individual Mtb CYP enzymes for in vitro growth under standard laboratory conditions. This is not surprising since a high number of genes found to be essential for in vitro growth were conserved in the degenerate genome of the leprosy bacillus, M. leprae (Sassetti et al. 2003). Even though an initial study indicated that cyp $128 a 1$ was among the essential genes unique to mycobacteria, this could not be confirmed in later TraSH studies (Sassetti et al. 2003; Lamichhane et al. 2003; Griffin et al. 2011; Zhang et al. 2012; DeJesus et al. 2017). These contradictory results could be due to the limited gene coverage of some of the transposon libraries. Interestingly, disruption of the orphan cyp136al provided a growth advantage in vitro (DeJesus et al. 2017). Even though cyp121al was found to be non-essential in these genome-wide transposon studies, cyp121al could only be knocked out in Mtb H37Rv after creating a merodiploid strain. This indicates that this gene is required for growth under in vitro conditions (McLean et al. 2008).

Transposon insertion studies were also conducted on bacterial cultures grown in conditions that the bacterium encounters during infection in the human host. These studies aimed to identify the mechanisms used by the bacterium to resist these insults. Griffin et al. identified cyp125al as the sole monooxygenase essential for $\mathrm{Mtb} \mathrm{H} 37 \mathrm{Rv}$ growth in cholesterol, an essential carbon source during Mtb infection. Furthermore, cyp125al was found to be essential during mouse infection (Sassetti and Rubin 2003). Although cyp125al was not found to be required for macrophage infection, it is part of the fadE28 locus, which is a critical operon involved in lipid transport, lipid degradation and assimilation of exogenous lipids from host cell membranes (Cole et al. 1998; McKinney et al. 2000; Rengarajan et al. 2005).

Both FdxA and FdxC (the two 7Fe-ferredoxins) were found to be essential for Mtb in vitro (Sassetti et al. 2003; DeJesus et al. 2017). For FdxA, essentiality was predicted using a pathway enrichment method (Xu et al. 2014). Several transposon mutagenesis studies indicate that individual redox partners may not be essential under certain growth conditions, such as cholesterol rich conditions or during infection in vivo (Lamichhane et al. 2003; Sassetti et al. 2003; Sassetti and Rubin 2003; Lamichhane et al. 2005; Rengarajan et al. 2005; Jain et al. 2007; Dutta et al. 2010; Griffin et al. 2011; Zhang et al. 2012; DeJesus et al. 2017). These results could be explained by redundancy of redox partners in CYP-mediated reactions previously shown not only for Mtb (Ortega Ugalde et al. 2018a) but also for other bacteria, such as M. marinum, Sorangium cellulosum So ce56 and
Streptomyces peucetius DoxA (Ewen et al. 2009; Rimal et al. 2015; Child et al. 2018).

\section{Mtb CYPs and cognate redox partners function}

Only a handful of the $20 \mathrm{Mtb}$ CYPs and cognate redox partners have been structurally and biochemically characterized. In this section, we summarize the current knowledge of the (partially) characterized Mtb CYP enzymes and associated redox partners. For a more elaborate discussion, see also (McLean et al. 2006a, 2007, 2010; McLean and Munro 2008; Ouellet et al. 2010a; Ortiz de Montellano 2018).

\section{CYP51B1: the first prokaryotic sterol demethylase}

Cyp51b1 was the first prokaryotic sterol demethylase gene identified in a bacterial genome. Spectroscopic analysis of the recombinant CYP51B1 showed that the $\mathrm{P} 450$ form rapidly converted to the $\mathrm{P} 420$ species. The stability of the P450 form was increased when it was bound to its cognate substrate analog estriol (McLean et al. 2006b; Dunford et al. 2007). CYP51B1 was the first Mtb CYP enzyme for which crystal structures were unraveled in the ligand-free and ligand-bound states. The enzyme was co-crystalized with azole compounds. Azoles were shown to bind with high affinity to CYP51B1, with a $K_{D}$ equal to $0.18,0.2,0.3$, and $2.1 \mu \mathrm{M}$ for clotrimazole, miconazole, econazole, and voriconazole, respectively (Aoyama et al. 1998; Podust et al. 2001, 2004). Mtb CYP51B1 displayed sterol demethylase activity with lanosterol and dihydrolanosterol as substrates. In addition, the plant sterol obtusifoliol was converted to the respective 8,14-diene products when reconstituted with cognate and surrogate bacterial redox partners (Fig. 1) (Bellamine et al. 1999; Zanno et al. 2005). However, the relevance of this activity to mycobacterial physiology remains unclear, since the complete sterol biosynthetic pathway is lacking in Mtb (McLean and Munro 2008). The unknown physiological role combined with the non-essentiality may limit the suitability of CYP51B1 as a drug target in Mtb.

\section{CYP121: bacterial secondary metabolism}

CYP121A1 catalyzes the formation of a carbon-carbon bond between the two tyrosyl carbon atoms of a cyclodipeptide cyclo(L-Tyr-L-Tyr) (cYY) yielding mycocyclosin (Fig. 1) (Belin et al. 2009). The physiological role of mycocyclosin for Mtb remains unknown. However, several cyclic dipeptides have been shown to have an impact on bacterial physiology. For instance, the cyclo(Phe-Pro) inhibited the production of virulence factors in Vibrio cholerae (Park et al. 2006; McLean et al. 2008, 2010). CYP121A1 is considered a highly selective CYP, since it does not efficiently metabolize any cYY analogs (Fonvielle et al. 2013). Spectroscopic characterization of 


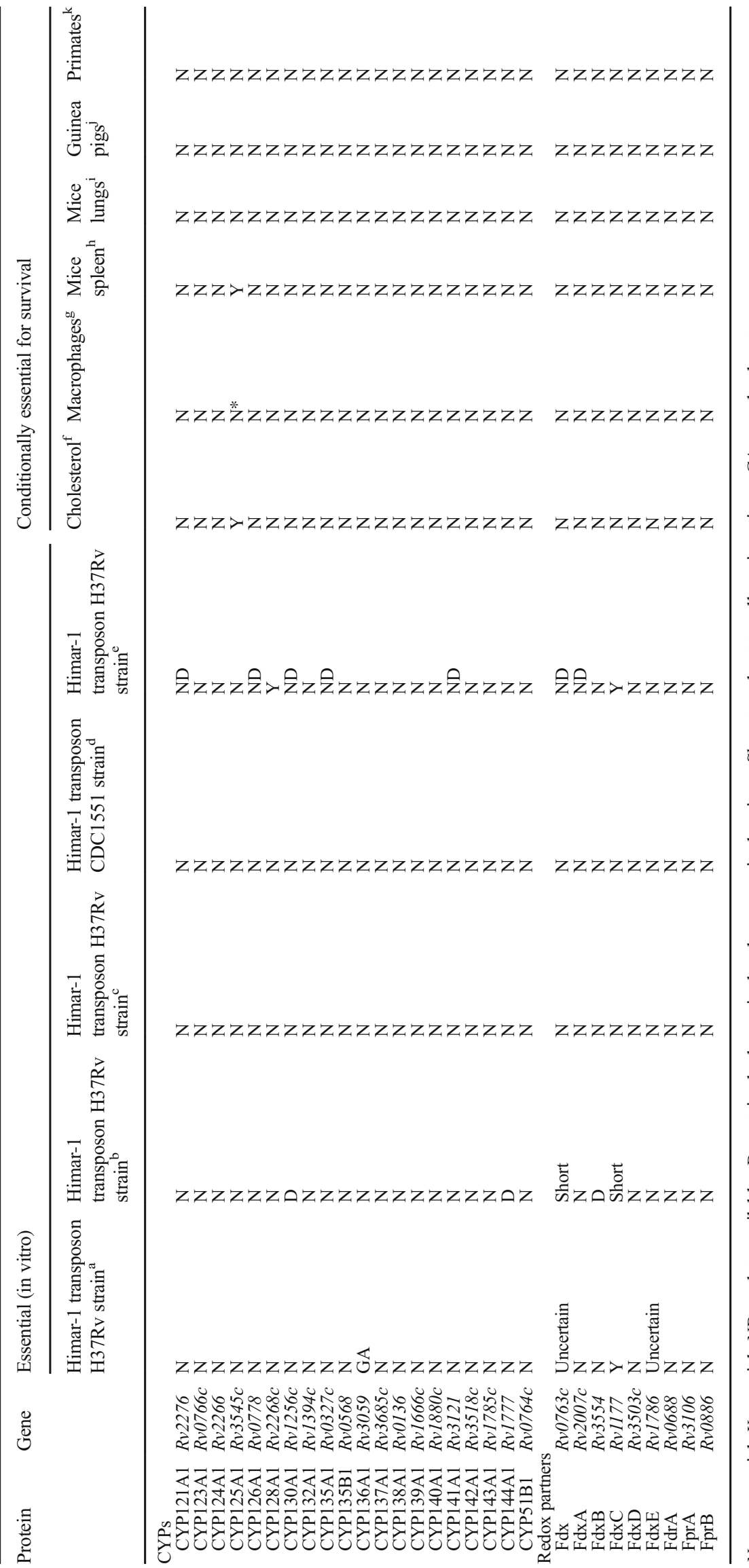




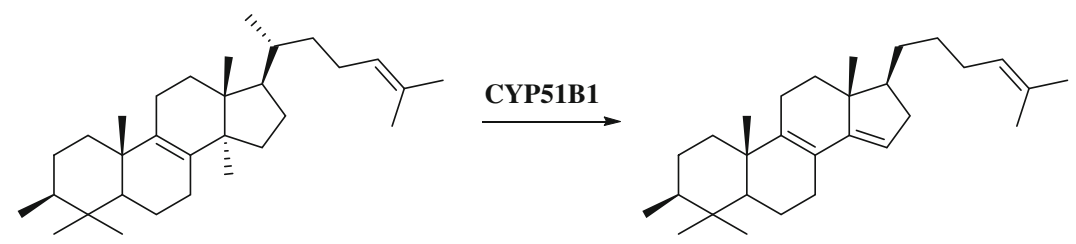

Lanosterol

4-4'-dimethylcholestatrienol<smiles>O=C1NC(Cc2ccc(O)cc2)C(=O)NC1Cc1ccc(O)cc1</smiles>

CYP121A1<smiles>O=C1NC(Cc2ccc(O)c(Cl)c2)C(=O)NC1Cc1ccc(O)cc1</smiles>

Mycocyclosin<smiles>CC(C)CCCC(C)CCCC(C)CCCC(C)CC(=O)O</smiles>

CYP124A1<smiles>CC(CO)CCCC(C)CCCC(C)CCCC(C)CC(=O)O</smiles><smiles>CC(C)CCC[C@H](C)[C@H]1CC[C@H]2[C@@H]3CC=C4C[C@@H](O)CC[C@]4(C)[C@H]3CC[C@]21C</smiles><smiles>[CH][C@@H](CCCC(C)CO)[C@H]1CCC2[C@H]3CC=C4C[C@H](O)CC[C@]4(C)[C@H]3CC[C@]21C</smiles>

Cholesterol

27-hydroxycholesterol<smiles>CC(C)=CCC(C)CC(C)=CC(C)=CCC(C)(C)C(C)CCCC(C)=CCC1=C(C)C(=O)c2ccccc2C1=O</smiles><smiles>COc1ccc2c(c1)C13CCCCN(CC1C2)C3C</smiles>

Dextromethorphan

Fig. 1 Substrates and reactions for Mtb CYP enzymes. CYP51B1 sterol demethylase catalyzes oxidative removal of $14 \alpha$-methyl group from lanosterol, dihydrolanosterol, and obtusitol (Bellamine et al. 1999). CYP121A1 catalyzes the oxidative coupling of the two tyrosyl atoms (Belin et al. 2009). CYP124A1 catalyzes the $\omega$-hydroxylation of phytanic acid and other methyl branched-chains fatty acids (Johnston

recombinant CYP121A1 showed the same P450 collapse of the CO-ferrous state as previously described for CYP51B1.<smiles>COc1ccc2c(c1)C13CCCC(C1)NC2CC3[Mg][Mg]</smiles>

\section{3-methoxymorphinan}

et al. 2009). CYP125A1 and CYP142A1 catalyze the 27-hydroxylation of cholesterol (McLean et al. 2009; Capyk et al. 2009; Driscoll et al. 2010; Ouellet et al. 2010a). CYP130A1 catalyzes N-demethylation of dextromethorphan (Ortega Ugalde et al. 2018). CYP128A1 catalyzes the oxidative hydroxylation of menaquinone MK-9 (DH-2) (Holsclaw et al. 2008)

However, this event was reversible at lower $\mathrm{pH}$, suggesting that the state was dependent on the protonation of the cysteine 
thiolate (Cys345) to thiol (Dunford et al. 2007). CYP121A1 binds with high affinity to azole drugs $\left(K_{D}\right.$ equal to 0.027 , $0.073,0.136$, and $8.61 \mu \mathrm{M}$ for econazole, clotrimazole, miconazole and fluconazole, respectively (McLean et al. 2002a, b; Seward et al. 2006). CYP121A1-fluclonazole crystal structure (PDB 2IJ7) demonstrates that azole coordination of P450 heme can occur via a bridging water molecule, as well as directly to the iron (Seward et al. 2006).

\section{CYP124A1, CYP125A1, and CYP142A1: the cholesterol and fatty acid monooxygenase CYPs}

CYP124A1 catalyzes $\omega$-hydroxylation reactions with a significant preference for methyl-branched lipids (Fig. 1) (Johnston et al. 2009). Several studies have shown that CYP124A1, CYP142A1, and CYP125A1 are involved in the successive oxidations of the aliphatic side chain of cholesterol and cholest-4-en-3-one at carbon position 27 to the alcohol, aldehyde, and the carboxylic acid (Fig. 1) (Johnston et al. 2010). CYP126A1 may have a related function/activity, as it shows a $37 \%, 36 \%$, and $32 \%$ amino acid sequence homology with CYP124A1, CYP125A1, and CYP142A1, respectively (Ouellet et al. 2010a). CYP126A1 showed a strong preference for the binding of aromatics and chlorophenol moieties (Hudson et al. 2014). In the presence of surrogate redox partners from Spinacea oleracea, CYP124A1, CYP142A1, and CYP125A1 oxidized the cholesterol side chain to carboxylic acid. This reaction is a prerequisite for the entry of cholesterol into the $\beta$-oxidation pathway (Johnston et al. 2010). However, this sequential metabolic activity was not seen when several cognate redox partners were used to reconstitute the system (Ortega Ugalde et al. 2018a). CYP125A1 is the most efficient catalyst, followed by CYP142A1 and finally CYP124A1 (Johnston et al. 2010; Ouellet et al. 2010b). Utilization of host cholesterol as a carbon source enables Mtb to persist in macrophages and survive the harsh environment of the granuloma inside the human lung (Ouellet et al. 2011; Lee et al. 2013; Wilburn et al. 2018). Knockout of the intracellular growth (igr) locus (from $R v 3545 c$ to $R v 3540 c$, which includes cyp 125a1) led to accumulation of cholest-4-en-3-one, which not only prevented the growth of Mtb in cholesterol-rich medium, but also when grown with acetate, glucose and glycerol as sole carbon source (Chang et al. 2007, 2009; Frank et al. 2016). Hence, targeting CYPs involved in cholesterol catabolism could be a contribution to the antitubercular therapy (VanderVen et al. 2015).

\section{CYP128A1: a possible role in virulence}

Sassetti et al. initially identified cyp $128 a 1$ as essential for Mtb growth in vitro. Subsequent transposon mutagenesis studies did not validate this essentiality (Table 1). Several attempts to heterologously express CYP128A1 have been unsuccessful, preventing its biochemical and structural characterization. The operon containing cyp128a1 is comprised of three genes involved in the biosynthesis of a sulfated metabolite, S881, also known as sulfomenaquinone. It was hypothesized that CYP128A1 catalyzes the required hydroxylation of dihydromenaquinone (MK-9 DH2), which is further sulfonated by a sulfotransferase ( $\mathrm{Sft} 3$ encoded by $R v 2267 c$ ) yielding S881 (Fig. 1) (Cole et al. 1998; Holsclaw et al. 2008). S881 is a sulfolipid (SL-1) located in the outer membrane cell wall, where it acts as negative regulator of virulence (Mougous et al. 2006; ten Bokum et al. 2008; Jackson 2014). Hence, assuming that CYP128A1 is indeed a quinol hydroxylase, it is an unlikely therapeutic target for Mtb.

\section{CYP130A1: an orphan enzyme}

Cyp130al, as well as cyp141al, are not required for Mtb growth in vitro. Furthermore, these genes are absent in the closely related species Mycobacterium bovis, suggesting that, if they play a role in virulence, this must be specific for Mtb. Cyp130a1 is located alongside the same functional operon as $R v 1258 c$, a gene encoding a putative tetracycline/ aminoglycoside resistance (TAP)2-like efflux pump, which is upregulated treatment with tetracycline, streptomycin, erythromycin, and rifampicin (unlike cyp130al, as discussed in section 5) and has been associated with efflux-mediated resistance in MDR-TB (Siddiqi et al. 2004; Morris et al. 2005; Jiang et al. 2008; Burian et al. 2012; Boot et al. 2018). Yet, no direct functional association has been reported between cyp130a1 and Rv1258c. Recently, it was shown that CYP130A1 can catalyze the N-demethylation of dextromethorphan yielding 3-methoxymorphinan (Fig. 1) (Ortega Ugalde et al. 2018b). Although dextromethorphan cannot be considered a physiological substrate for this enzyme, it does provide a starting point for (1) the identification of bacterial reactions CYP130A1 may catalyze and (2) the identification of inhibitors. Nevertheless, because of the lack of comprehensive data on the impact of CYP130A1 on Mtb virulence, its potential as a drug target remains to be determined.

\section{CYP139A1: a possible host-response modulator and/or detoxifying enzyme}

CYP139A1 (Rv1666c) is conserved across different mycobacterium species, such as M. marinum (MMAR2475), M. bovis (Mb1694c), and M. leprae (ML1238c, pseudogene), as part of a cluster consisting of polyketide synthase genes ( $p k s 11,9$, and 17) and a macrolide transport ATP-binding protein $\mathrm{ABC}$ transporter gene. Polyketides are lipid-like molecules that are smaller than known protein toxins but have potent biological activities, such as, antibiotic (erythromycin), immunosuppressant (rapamycin), and antifungal (amphotericin B). In Mtb, the majority of the PKS-encoding genes have been linked to 
specific biosynthetic pathways required for the production of unique lipids or glycolipid conjugates that are critical for virulence and/or components of the organized outer membrane of the mycobacterial cell envelope. As an example, Mtb was shown to be capable of altering essential host functions by the release of polyketides that can induce a G0/G1 cell cycle arrest in the macrophages. As a result, mycobacteria are capable of challenging innate killing mechanisms and evade the adaptive immune system as non-cycling cells are less likely to be killed by cytotoxic T cells (Nishioka and Welsh 1994; Cumming et al. 2017). Pks 9 is an immunogenic protein (Kumar et al. 2011), whereas pks 17 (together with pks8, Rv1662) is involved in the production of methyl-branched fatty acids which are minor components of sulfolipids and acyltrehaloses (Dubey et al. 2003). Pks11 could be involved in the assembly of alkylpyrones from fatty acyl-CoA and malonyl-CoA (Saxena et al. 2003; Gokulan et al. 2013), but the production of long-chain $\alpha$-pyrone metabolites in Mtb has not been shown. Hence, CYP139A1 could play a conserved role in the modification and/or transport of these Psk-derived molecules and it could be associated with the host-pathogen interactions. On the other hand, the observation that CYP139A1 is induced after exposure to antibiotics (see below) is intriguing and may suggest a role in detoxification.

\section{CYP143A1: component of the ESX-5 secretion locus}

The gene encoding the orphan enzyme CYP143A1 lies adjacent to Rv1786 encoding FdxE. This proximity suggests a CYP/redox partner association. Indeed, a significant binding affinity between FdxE and CYP143A1 was demonstrated with a $K_{D}$ value equal to $10^{-7} \mathrm{M}$ (Lu et al. 2017). In Mtb and several closely related species, cyp143al is part of the esx-5 locus. Most genes of this esx-5 locus are coding for substrates or components of the ESX-5 protein secretion machinery. This ESX-5 secretion system completes a multitude of functions, linked to the many different Pro-Glu (PE) and Pro-Pro-Glu (PPE) protein substrates of the system. Some of these proteins remain in the cell envelope, where they are important for modifying the cell permeability and uptake of hydrophobic carbon sources (Abdallah et al. 2009; Ates et al. 2015). In addition, Mtb ESX-5 system mediates the reduction of pro-inflammatory cytokine secretion by macrophages and induces a caspase-independent cell death in macrophages after phagosomal escape of the bacteria enabling the bacteria to infect neighboring cells (Abdallah et al. 2008, 2011). Also, ESX-5 components are upregulated during phosphate-limiting conditions (Elliot and Tischler 2016). Even though the specific role of cyp 143al remains unclear, its association with the esx-5 locus may reflect a pivotal contribution to components of the transport channel. Furthermore, ESX-5 transposon insertion mutants in the gene encoding CYP143A1 Mtb were attenuated both in macrophages and in the immunodeficient mouse infection model (Bottai et al. 2012; Sayes et al. 2012). The same holds true for MMAR_2666 (cyp 143al homolog in M. marinum) during infection in RAW, THP1, or CLC cell lines (Weerdenburg et al. 2015). These results confirm that CYP143A1 might have a conserved pathogenic role and therefore highlights its potential use as a drug target.

\section{Cognate redox partners for Mtb CYPs}

The relatively low number of redox partners compared to the number of CYP genes in Mtb implies that these redox proteins are promiscuous in mediating electron transfer. However, some CYPs may have evolved with protein binding sites that are specific for (a) certain redox partner(s). Recently, it was shown that the activity of a small selection of Mtb CYPs was supported by several cognate redox partners in vitro (Ortega Ugalde et al. 2018a). Both Fdx and FdxD supported CYP121A1 catalytic activity with comparable efficiencies whereas FdxD and FdxE supported in vitro reconstitution of cholesterol hydroxylation by Mtb CYP124A1, CYP125A1, and CYP142A1, although with lower efficiency for FdxE. Catalytic efficiencies were equal for the two different FNRs (FdrA and FprA), indicating a flexible CYP/FNR/Fd catalytic system in vivo. Previous studies have shown the ability of the FprA-Fdx redox system to reduce CYP51B1 in vitro (McLean et al. 2006a). Moreover, the FdrA-Fdx complex was capable of supporting CYP51B1 activity through the same electron transfer system (Zanno et al. 2005). FdxA was the only ferredoxin unable to transfer electrons to any of the studied CYPs (Ortega Ugalde et al. 2018a). In addition, FdxC, which has not been successfully expressed yet, is required for optimal growth of Mtb in vitro suggesting a key role in shuttling electrons (Sassetti et al. 2003; DeJesus et al. 2017).

Characterization of the electron transfer capabilities of FdxC, FdxB, and FprB, to (all) Mtb CYPs could contribute to understanding the complex biochemistry of the CYP/FNR/ Fd network.

\section{Mtb CYPs and cognate redox partners expression levels}

Mtb encounters a number of physiological stresses that trigger coordinated stress responses orchestrated by protein expression regulation. A summary of transcriptome analyses under different insults focusing on Mtb CYPs and their cognate redox partners is presented in Table 2. Induced expression as part of the Mtb adaptive response could indicate an important role in survival. 
Table 2 Expression levels of Mtb CYPs and cognate redox partners

\begin{tabular}{|c|c|c|c|c|c|c|c|c|c|c|c|}
\hline \multirow[t]{2}{*}{ Protein } & \multirow[t]{2}{*}{ Gene } & \multicolumn{10}{|l|}{ Stress } \\
\hline & & $\begin{array}{l}\text { Stationary } \\
\text { phase }^{\mathrm{a}}\end{array}$ & Starvation $^{\mathrm{b}}$ & $\begin{array}{l}\mathrm{pH} \\
\text { stress }^{\mathrm{c}}\end{array}$ & $\begin{array}{l}\mathrm{NO} \\
\text { treatment } \mathrm{d}^{\mathrm{d}, \mathrm{e}}\end{array}$ & $\begin{array}{l}\mathrm{CO} \\
\text { treatment }^{\mathrm{f}}\end{array}$ & Hypoxia $^{\mathrm{g}, \mathrm{h}, \mathrm{i}}$ & $\begin{array}{l}\text { High } \\
\text { temperature }^{j}\end{array}$ & Phagocytosis ${ }^{\mathrm{k}}$ & $\begin{array}{l}\text { DNA } \\
\text { damage }^{1}\end{array}$ & $\begin{array}{l}\text { Salicylate } \\
\text { treatment }^{\mathrm{m}}\end{array}$ \\
\hline \multicolumn{12}{|l|}{ CYPs } \\
\hline CYP121A1 & $R v 2276$ & $\downarrow$ & $\uparrow$ & - & $\downarrow$ & - & - & - & - & - & - \\
\hline CYP123A1 & $R v 0766 c$ & - & $\uparrow$ & - & - & - & - & $\uparrow$ & - & - & - \\
\hline CYP124A1 & $R v 2266$ & - & - & - & - & - & - & - & - & - & - \\
\hline CYP125A1 & $R v 3545 c$ & - & $\uparrow$ & - & - & - & - & - & - & - & - \\
\hline CYP126A1 & $R v 0778$ & - & $\uparrow$ & - & - & - & - & - & - & - & - \\
\hline CYP128A1 & $R v 2268 c$ & $\downarrow$ & $\uparrow$ & - & - & - & - & - & - & - & - \\
\hline CYP130A1 & $R v 1256 c$ & $\downarrow$ & - & - & - & - & - & - & - & - & - \\
\hline CYP132A1 & $R v 1394 c$ & - & $\uparrow$ & - & - & - & - & - & - & - & - \\
\hline CYP135A1 & $R v 0327 c$ & - & $\uparrow$ & - & - & - & - & - & - & - & - \\
\hline CYP135B1 & $R v 0568$ & - & $\uparrow$ & - & - & - & - & - & - & - & - \\
\hline CYP136A1 & $R v 3059$ & - & $\uparrow$ & - & - & - & $\uparrow$ & - & - & - & - \\
\hline CYP137A1 & $R v 3685 c$ & $\downarrow$ & $\uparrow$ & - & - & - & - & - & - & - & - \\
\hline CYP138A1 & Rv0136 & $\downarrow$ & $\uparrow$ & - & - & - & - & $\uparrow$ & - & - & - \\
\hline CYP139A1 & $R v 1666 c$ & - & - & - & - & - & - & - & - & - & - \\
\hline CYP140A1 & $R v 1880 c$ & $\downarrow$ & $\uparrow$ & - & - & - & - & - & - & - & - \\
\hline CYP141A1 & $R v 3121$ & - & $\downarrow$ & - & - & - & - & - & - & - & - \\
\hline CYP142A1 & $R v 3518 c$ & - & $\uparrow$ & - & - & - & - & - & - & - & - \\
\hline CYP143A1 & $R v 1785 c$ & $\downarrow$ & - & - & - & - & - & - & - & - & - \\
\hline CYP144A1 & $R v 1777$ & $\downarrow$ & - & - & - & - & - & - & - & - & - \\
\hline CYP51B1 & $R v 0764 c$ & - & $\uparrow$ & - & - & - & - & - & - & - & - \\
\hline \multicolumn{12}{|l|}{ Redox partners } \\
\hline $\mathrm{Fdx}$ & $R v 0763 c$ & - & - & - & - & - & - & - & - & - & - \\
\hline $\mathrm{FdxA}$ & $R v 2007 c$ & - & $\downarrow$ & $\uparrow$ & $\uparrow$ & $\uparrow$ & $\uparrow$ & $\uparrow$ & $\uparrow$ & - & - \\
\hline $\mathrm{FdxB}$ & $R v 3554$ & - & - & - & - & - & - & - & - & - & - \\
\hline $\mathrm{FdxC}$ & $R v 1177$ & - & $\downarrow$ & - & - & - & - & - & - & - & - \\
\hline $\mathrm{FdxD}$ & $R v 3503 c$ & - & $\uparrow$ & - & - & - & - & - & - & - & - \\
\hline $\mathrm{FdxE}$ & $R v 1786$ & - & - & - & - & - & - & - & - & - & - \\
\hline FdrA & $R v 0688$ & - & $\uparrow$ & - & - & - & - & - & - & - & - \\
\hline FprA & Rv3106 & - & - & - & $\downarrow$ & - & - & - & - & - & - \\
\hline FprB & $R v 0886$ & $\uparrow$ & - & - & - & - & $\uparrow$ & - & - & - & - \\
\hline
\end{tabular}

${ }^{\mathrm{a}}$ Hampshire et al. 2004

${ }^{\mathrm{b}}$ Betts et al. 2002

${ }^{\mathrm{c}}$ Fisher et al. 2002

${ }^{\mathrm{d}}$ Voskuil et al. 2003

${ }^{\text {e }}$ Namouchi et al. 2016

${ }^{\mathrm{f}}$ Shiloh et al. 2008

${ }^{\mathrm{g}}$ Sherman et al. 2001

${ }^{\text {h }}$ Bacon et al. 2004

${ }^{\text {i } V o s k u i l ~ e t ~ a l . ~} 2004$

${ }^{j}$ Stewart et al. 2002

${ }^{\mathrm{k}}$ Schnappinger et al. 2003

${ }^{1}$ Namouchi et al. 2016

${ }^{\mathrm{m}}$ Denkin et al. 2005 


\section{Stress response}

During latent infection Mtb is thought to survive in granulomas by entering a non-replicating state (Lenaerts et al. 2015). This condition is the bacterial response to a number of different stimuli, such as lack of nutrients, oxygen depletion, and high concentrations of NO (Betts et al. 2002; Voskuil et al. 2004; Bacon et al. 2004). Transcriptomic studies conducted under conditions that stimulate nutrient depletion have revealed that from the Mtb CYP complement (CYPome), only the expression of cyp $128 \mathrm{al}$ was upregulated, whereas the remaining CYPs showed a minimal alteration in their expression levels (Betts et al. 2002). cyp128a1 induction was also observed upon overproduction of the transcriptional regulators (TRs) WhiB2 and SigF, which are known to be induced as a result of nutrient depletion and thought to be involved in promoting bacterial survival and proliferation during infection in lung granulomas (Fig. 2) (Sherman et al. 2001; Bacon et al. 2004; Voskuil et al. 2004; Rustad et al. 2014). Only cyp136a1 expression was upregulated in response to hypoxic conditions (Sherman et al. 2001; Bacon et al. 2004; Voskuil et al. 2004). Likewise, cyp 136al upregulation was also seen by overproduction of WhiB3, a redox-sensitive TR responsive to NO and
$\mathrm{O}_{2}$ as well as upon overproduction of Rv0195, a LuxR transcription factor involved in bacterial virulence in human macrophage-like cells and murine tissues (Fig. 2) (Fang et al. 2013; Rustad et al. 2014). TRs Rv0238 and Rv3058c belong to the TetR family and both regulate efflux pumps and transporters, which are involved in antibiotic resistance and confer tolerance against toxic compounds (Cagliero et al. 2005; Guazzaroni et al. 2005; Lin et al. 2005; Akiba et al. 2006). Interestingly, overproduction of these two TRs yielded the transcriptional induction of several Mtb CYPs and associated redox partners, such as cyp128a1, cyp136a1, cyp143a1, cyp136a1, $F d x$, and $F d x A$, suggesting an involvement in antibiotic resistance pathways (Fig. 2) (Rustad et al. 2014). In contrast, the expression of virtually all Mtb CYPs and redox partners genes was downregulated in the stationary phase following progressive nutrient depletion, which could be explained by the lower transcriptional activity mycobacteria undergo under nutrient starvation (Betts et al. 2002; Hampshire et al. 2004). The number of transcripts of FdxA was increased in all conditions known to induce the dormancy regulon (DosR) regulon, especially by reduced $\mathrm{O}_{2}$ tension, which induces a switch to anaerobic metabolism (Sherman et al. 2001). In addition, FdxA is upregulated upon activation of the DosR
Fig. 2 Two-dimensional hierarchical clustering of $\mathrm{Mtb}$ CYPs and cognate redox partners expression profiles after transcription factor overexpression. The individual genes are represented on the $x$ axis and the transcription factors are indicated on the $y$ axis. Red indicates upregulation whereas green indicates downregulation and white indicates no change relative to time zero control. Data retrieved from Rustad et al. 2014

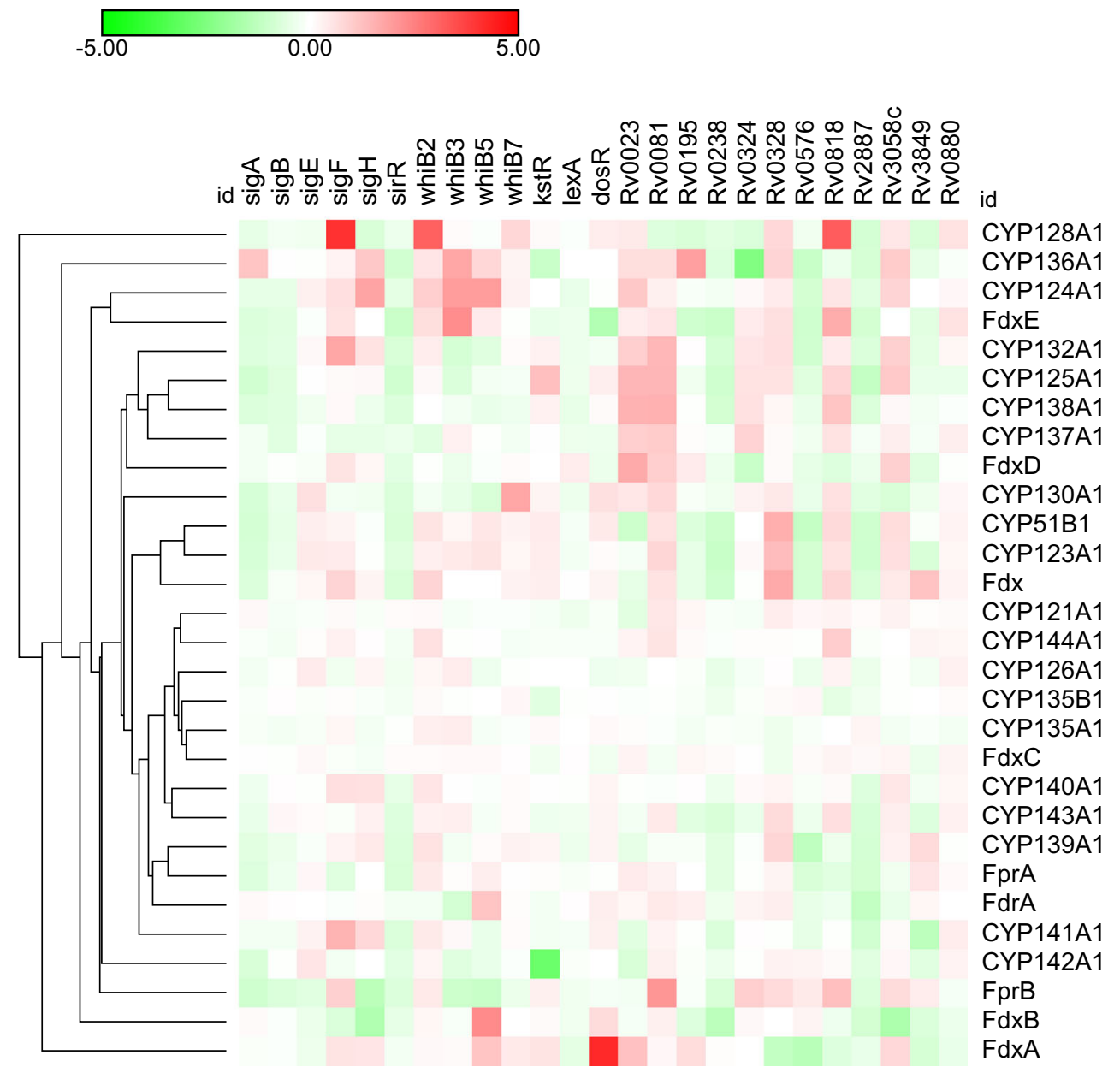


regulon, which is comprises a set of genes that is essential for the pathogen's ability to persist during lengthy hypoxia and to rapidly recover from non-respiratory dormancy (Fig. 2) (Rustad et al. 2014). Only FdxA showed an increased expression after $\mathrm{pH}$ stress, phagocytosis, and carbon monoxide (CO) treatment (Table 2). There was also a significant change in its expression level during mycobacterial growth in the immunecompetent $(\mathrm{BALB} / \mathrm{c})$ and the severe combined immunedeficient (SCID) mice (Fischer et al. 2002; Voskuil et al., 2003; Talaat et al. 2004; Shilou et al. 2008; Namouchi et al. 2016).

Overproduction of KstR, a highly conserved TR that regulates a large set of gene-encoding proteins involved in cholesterol catabolism, resulted in a high induction of cyp $125 \mathrm{al}$. In contrast, the other CYPs related to cholesterol metabolism were downregulated (cyp142al) or unchanged in expression (cyp124a1 and cyp126al) (Fig. 2) (Rustad et al. 2014). These results are in line with the reported induction levels of cyp142a1 in cholesterol-rich growth conditions (Johnston et al. 2010). These results suggest that even though CYP142A1 is able to catalyze cholesterol oxidation, CYP125A1 is the main monooxygenase involved in this pathway.

Bacteria respond to DNA damage by mounting a coordinated stress response; the so-called SOS response. This response is governed by the DNA repair genes recA and its cognate repressor lexA. The Mtb CYPs and their cognate electron-transfer partners are not part of the SOS box response. Therefore, it is not surprising that their expression levels remained unchanged upon DNA damage or in response to overproduction of LexA (Table 2 and Fig. 2) (Little 1991; Davis et al. 2002; Rustad et al. 2014; Namouchi et al. 2016).

A number of TRs mediate the regulation of genes involved in resistance to a diverse array of antibiotics that target different pathways in Mtb. For example, SigB is specifically involved in tolerance to ethambutol and isoniazid, whereas sigE null mutant strains are more sensitive to vancomycin, rifampin, streptomycin, gentamicin, isoniazid, and ethambutol (Pisu et al. 2017). The TRs Rv0324 and Rv0880 comprise the tolerance network to the recently marketed antitubercular drug, bedaquiline (Peterson et al. 2016). On the other hand, WhiB7 shows a more generic spectrum controlling the expression of a plethora of antibiotic resistant genes, such as tap (Rv1258c) coding for an efflux pump that provides low-level resistance to aminoglycosides and tetracycline or erm $(R v$ 1988) homologous to ribosomal methyltransferases and conferring MLS (macrolide, lincosamide, and streptogramin) resistance (De Rossi et al. 2002; Buriankova et al. 2004; Burian et al. 2013). Figure 2 shows that overproduction of SigB and SigE had little effect on expression levels of Mtb CYPs and redox partners. In contrast, cyp130al was slightly upregulated. The same holds true for overproduction of the TRs $R v 0324$ and $R v 0880$ (both involved in bedaquiline tolerance) which are both result in upregulation of cyp128a1, cyp137a1, fdxE, and $\operatorname{fpr} B$. Moreover, overproduction of WhiB7 led to increased transcripts of cyp128a1, cyp130a1, and fdxA, suggesting that they are involved in the dealing with the stress consequent to bedaquiline exposure (Fig. 2) (Rustad et al. 2014). Interestingly, expression of some of these TRs, such as whiB7, is upregulated by antibiotic treatment, as well as by certain (physiological) stresses including iron starvation and heat shock (Geiman et al. 2006).

Figure 2 depicts the TRs that are involved in the expression of Mtb CYP and redox partners (Rustad et al. 2014). Little is known about several TRs depicted in Fig. 2, such as Rv0081 and Rv0818; however, it is clear that they play a role in CYP biology and are possibly involved in drug tolerance.

\section{Antibiotic exposure response}

Analysis of the transcriptome response of Mtb to antibiotics is a powerful approach to unveil the pathways contributing to drug resistance and may provide new insights relevant to antimycobacterial drug discovery. Recently, Boot et al. studied the stress-fingerprint of Mtb upon exposure to subinhibitory concentrations of first- and second-line TB antibiotics with known targets (Boot et al. 2018). In Fig. 3, the transcriptional regulation of Mtb CYPs and redox partners after exposure to these compounds for 4 and $24 \mathrm{~h}$ is depicted. It was observed that Mtb mounts a global stress response with similar gene induction/repression to antibiotics, regardless of their cellular target. The antibiotics studied included ciprofloxacin, ethambutol, isoniazid, streptomycin, and rifampicin. Ciprofloxacin inhibits DNA unwinding; ethambutol and isoniazid both target the mycobacterial cell wall; streptomycin inhibits ribosomes; and rifampicin, inhibits RNA polymerase. Furthermore, comparison of the transcriptional response of Mtb at the selected two different time points showed virtually identical overlap, suggesting that Mtb CYPs and associated redox partners play a very specific and robust role upon antibiotic stress (Fig. 3a, b).

Clustering the transcriptional response revealed that cyp139a1, cyp121a1, cyp126al, and cyp137al together with $\mathrm{FdxB}$, was the most prominently upregulated cluster for all five drugs (Fig. 3). Interestingly, and as previously mentioned, cyp139a1 is immediately downstream of three polyketide synthase ( $p k s)$ genes and upstream of $R v 1667 c$, a gene encoding an ATP-binding cassette (ABC) superfamily transporter. The expression of the three $p k s$ is downregulated except for $p k s 17$ and $p k s 9$ genes (Rv1663 and $R v 1664$, respectively) upon exposure to ciprofloxacin and rifampicin. In contrast, Rv1667c is also induced upon exposure to first-line antibiotics (Zhang et al. 2017; Boot et al. 2018). Furthermore, it can also be speculated that increased expression of cypl39al (or one of the other CYPs) contributes to the intrinsic resistance of Mtb to anti-TB agents. 
a

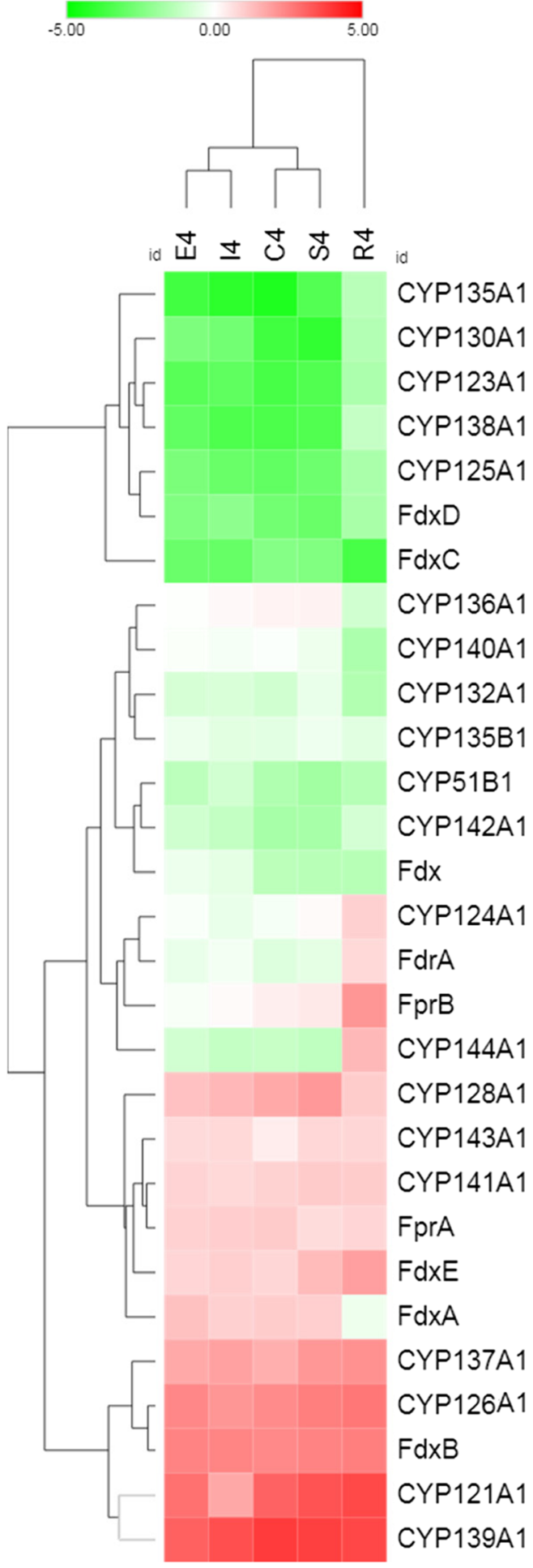

Fig. 3 Two-dimensional hierarchical clustering of Mtb CYPs and cognate redox partners expression profiles in response to first- and second-line antibiotic exposure. a After 4-h exposure and b after 24-h exposure. The individual genes are represented on the $x$-axis and the

Cyp143a1 and its tentative associated cognate redox partner, $R v 1786(\mathrm{FdxE})$, were upregulated after exposure to these b
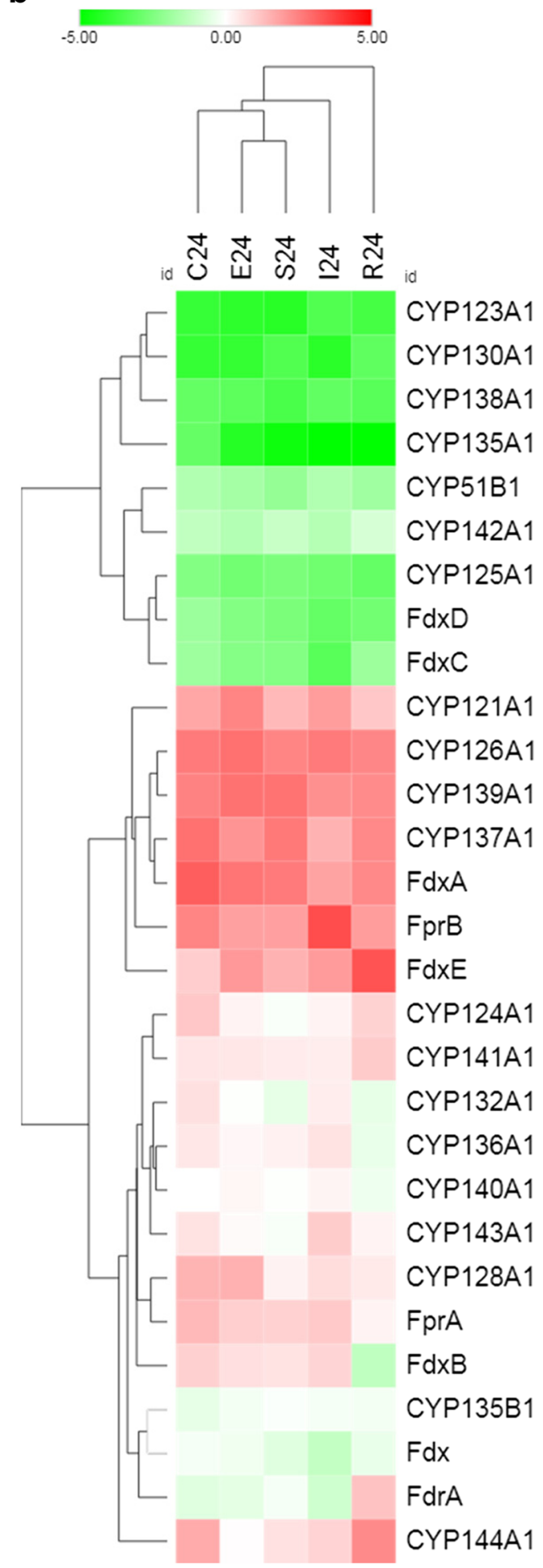

antibiotics are indicated on the $y$-axis. Red indicates upregulation whereas green indicates downregulation and white indicates no change relative to time zero control. $\mathrm{C}=$ ciprofloxacin, $\mathrm{E}=$ ethambutol, $\mathrm{I}=$ isoniazid, $\mathrm{R}=$ rifampicin, $\mathrm{S}=$ streptomycin. Data retrieved from Boot et al. 2018

antibiotics (Fig. 3) (Boot et al. 2018). Furthermore, the expression of Rv1790, encoding PPE27, was also upregulated 
a
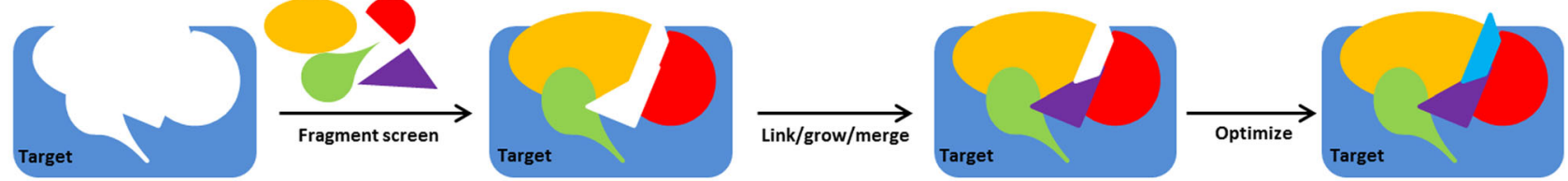

b

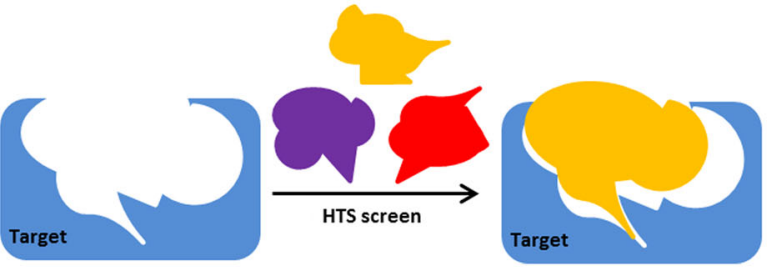

C<smiles>Nc1ccc(Sc2ccc(N3C(=O)c4ccc(N)cc4C3=O)cc2)cc1</smiles>

Compound 2

$\mathrm{K}_{\mathrm{d}}=1.08 \pm 0.05 \mathrm{uM}$

d<smiles>Nc1ccc2nccc(-n3cncn3)c2c1</smiles>

Compound 14 $\mathrm{K}_{\mathrm{d}}=28 \pm 4 \mathrm{uM}$<smiles>Oc1ccc(Nc2n[nH]c(-c3ccc(O)cc3)c2-c2ccc(O)cc2)cc1</smiles>

Compound 9 $\mathrm{K}_{\mathrm{d}}=15 \mathrm{uM}$<smiles>Cc1cccc(-n2cnc3cc(N)ccc32)c1</smiles>

Compound 4 $\mathrm{K}_{\mathrm{d}}=4.8 \pm 0.6 \mathrm{uM}$<smiles>Nc1ccc(-c2cccc(-c3c(-c4ccc(O)cc4)n[nH]c3N)c2)cc1</smiles>

Compound 15

$\mathrm{K}_{\mathrm{d}}=15 \mathrm{nM}$ e<smiles>O=C(NC(Cc1c[nH]c2ccccc12)C(=O)Nc1ccncc1)C1CCCCC1</smiles>

LP10

$K_{d}=1.7 \pm 0.08 u M$<smiles>Oc1ccc(-c2ccc(Cc3ccncc3)cc2)cc1</smiles>

Compound 128 $\mathrm{K}_{\mathrm{d}}=84 \mathrm{nM}$

Fig. 4 Schematic representation of the strategies for Mtb CYP inhibitors identification. a Fragment-based (FB), where fragments are screened against the target of interest, leading to identification of hits, which are linked/grown/merged and finally optimized to generate lead compounds. b HTS, where compounds are screened against the target of interest, leading to identification of hit compounds with often lack of optimal

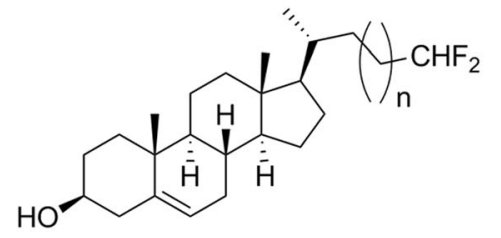

$\mathrm{n}=1$ compound 2 $\mathrm{n}=2$ compound 3

interactions with the target. $\mathbf{c}$ HTS identified high-affinity inhibitor-like binding heterocyclic arylamines for CYP130A1 (Podust et al. 2009). d FB identified high-affinity inhibitor-like compounds for CYP121A1 (Hudson et al. 2012, 2013; Kavanagh et al. 2016). e HTS identified and specifically synthetized inhibitors for CYP125A1/CYP142A1 (Chen et al. 2009; Ouellet et al. 2011; Brengel et al. 2016; Frank et al. 2016) 
whereas other genes in the ESX-5 cluster were downregulated or relatively unaffected (Boot et al. 2018). In addition, FdxA was also induced by exposure to anti-TB compounds, suggesting that this protein is a key player in pathways to resist insults Mtb may encounter in vivo (Fischer et al. 2002; Voskuil et al. 2003; Shilou et al. 2008; Namouchi et al. 2016; Boot et al. 2018). The same holds true for FdxB, after exposure to all four antibiotics (Fig. 3a, b).

The cluster with the strongest downregulation of transcription consisted of cyp135a1, cyp130a1, cyp123a1, and cyp125a1 together with the electron transfers FdxC and FdxD. A plausible explanation could be that these proteins are constitutively highly expressed (Ricagno et al. 2007). CYP125A1 was shown to be essential for Mtb growth in cholesterol. Its downregulation under antibiotic exposure is consistent with the capability of the bacteria to distinguish different stresses, triggering specific transcriptomic responses (Griffin et al. 2011).

The transcriptional response to bedaquiline was opposite to the results presented in Fig. 3 for the classical anti-TB drugs (Peterson et al. 2016). Cyp121a1, cyp126a1, cyp137al, and cyp141al were significantly downregulated, whereas cyp $125 a 1$ and $F d x E$ were clearly upregulated. This alteration in transcriptome response likely reflects the different mechanism of action of bedaquiline, namely inhibition of the $\mathrm{F}_{1} \mathrm{~F}_{0^{-}}$ ATP synthase of Mtb, preventing any specific response to be mounted. In addition, it could be the result of bedaquilineinduced decreased protein synthesis due to downregulation of ribosomal subunits (Koul et al. 2014).

Due to the absence of correlation between the transcriptional response of the CYPome after overproduction of several TRs (Fig. 2) and after exposure to anti-TB drugs (Fig. 3), it is not possible to identify TRs which are activated upon antibiotic exposure.

\section{Targeting Mtb CYPs: state of art}

Insights into the essentiality of Mtb CYPs and their natural redox partners and the transcriptomic response to external insults are useful to evaluate their potential as therapeutic targets to combat TB. In particular, CYP121A1 and CYP125A1/CYP142A1 are considered promising drug-targets, because several azole-drugs, such as econazole, clotrimazole, and miconazole, bind with high affinities to these Mtb CYPs. Moreover these compounds have been shown to be potent antimycobacterials in vitro, being effective even against persistent and multidrugresistant strains of Mtb (McLean et al. 2002b; Ahmad et al. 2006a, b; McLean and Munro 2008). In addition, the development of CYP inhibitors relies mostly on highthroughput compound screens (HTS) and fragment-based approaches which provide foundations for a more rational design of selective Mtb CYP inhibitors (Fig. 4a, b). HTS to find potent and highly selective inhibitors of
CYP126A1 and CYP130A1 has been performed (Podust et al. 2009; Hudson et al. 2014). In addition, these studies aimed to identify substrates for the orphan CYP126A1 and CYP130A1, which would help to define their physiological roles. This HTS screening on Mtb CYP130A1 identified some inhibitors, belonging to the heterocyclic arylamines which have been shown to cause toxicity issues, deterring their exploitation as antibiotics (Fig. 4c) (Podust et al. 2009; Kim and Guengerich 2005). Furthermore, fragment-based approaches have been applied to CYP121A1 (Hudson et al. 2012; Hudson et al. 2013; Kavanagh et al. 2016). These studies have led to the identification of high affinity type-II binding compounds, with $K_{D}$ values as low as $15 \mathrm{nM}$, high Mtb CYP selectivity and low off-target interaction with human CYPs (Fig. 4d) (Kavanagh et al. 2016). However, no significant inhibition of bacterial growth was detected for any of the lead compounds $\left(\mathrm{MIC}_{90} \geq 50 \mu \mathrm{M}\right)$ probably due to low membrane permeability and/or increased expression of efflux transporters (Kavanagh et al. 2016).

The CYP inhibitor LP10, initially discovered to block CYP51 from Trypanosoma cruzi, showed moderate inhibition of CYP125A1 (Fig. 4e) (Chen et al. 2009; Ouellet et al. 2011). Moreover, screening assays have identified a compound that can inhibit CYP125A1/CYP142A1 (C128), and has a $K_{D}$ equal to $85 \mathrm{nM}$ (Fig. 4e) (Brengel et al. 2016). Furthermore, two terminally truncated cholesterol analogs with fluorinated side chains were shown to inhibit growth of Mtb (Fig. 4e) (Frank et al. 2016). However, direct inhibition of CYP125A1 and/or CYP142A1 could not be confirmed and the observed growth inhibition was independent of the presence of CYP125A1 (Frank et al. 2016).

\section{Concluding remarks}

New anti-TB drugs are needed to fight resistance and combination therapies provide the most effective treatment of tuberculosis. As such, Mtb CYPs could provide one of the drug targets, as they conduct very specific roles for the pathogen. In addition, their uniqueness to $\mathrm{Mtb}$ highlights their attractiveness as therapeutic targets avoiding off-target toxicity. The transcriptional response upon external insults mimicking in vivo situation and drug exposure showed that Mtb CYPs and cognate redox partners might be involved in the adaptation of the pathogen to antibiotics. Further studies will focus on the further biochemical characterization of (orphan) CYPs and redox partners as well as defining the contribution of individual genes by using knockout or knockdown mutants to shed light on their physiological role and their plausible involvement in resistance to antibiotics. 
Funding This study was funded by The Netherlands Organization for Scientific Research NWO-AIMMS STAR Graduate Program (grant no. 022.005.031 to S. Ortega Ugalde).

\section{Compliance with ethical standards}

Conflict of interest The authors declare that they have no conflict of interest.

Ethical statement This article does not contain any studies with human participants or animals performed by any of the authors.

Open Access This article is distributed under the terms of the Creative Commons Attribution 4.0 International License (http:// creativecommons.org/licenses/by/4.0/), which permits unrestricted use, distribution, and reproduction in any medium, provided you give appropriate credit to the original author(s) and the source, provide a link to the Creative Commons license, and indicate if changes were made.

Publisher's note Springer Nature remains neutral with regard to jurisdictional claims in published maps and institutional affiliations.

\section{References}

Abdallah AM, Savage ND, van Zon M, Wilson L, VandenbrouckeGrauls CM, van der Wel NN, Ottenhoff TH, Bitter W (2008) The ESX-5 secretion system of Mycobacterium marinum modulates the macrophage response. J Immunol 181:7166-7175. https://doi.org/ 10.4049/jimmunol.181.10.7166

Abdallah AM, Verboom T, Weerdenburg EM, Gey van Pittius NC, Mahasha PW, Jiménez C, Parra M, Cadieux N, Brennan MJ, Appelmelk BJ, Bitter W (2009) PPE and PE-PGRS proteins of Mycobacterium marinum are transported via the type VII secretion system ESX-5. Mol Microbiol 73:329-340. https://doi.org/10.1111/ j.1365-2958.2009.06783.x

Abdallah AM, Bestebroer J, Savage ND, de Punder K, van Zon M, Wilson L, Korbee CJ, van der Sar AM, Ottenhoff TH, van der Wel NN, Bitter W, Peters PJ (2011) Mycobacterial secretion systems ESX-1 and ESX-5 play distinct roles in host cell death and inflammasome activation. J Immunol 187:4744-4753. https://doi. org/10.4049/jimmunol.1101457

Ahmad Z, Sharma S, Khuller GK (2006a) Azole antifungals as novel chemotherapeutic agents against murine tuberculosis. FEMS Microbiol Lett 261:181-186. https://doi.org/10.1111/j.1574-6968. 2006.00350.x

Ahmad Z, Sharma S, Khuller GK, Singh P, Faujdar J, Katoch VM (2006b) Antimycobacterial activity of econazole against multidrug-resistant strains of Mycobacterium tuberculosis. Int J Antimicrob Agents 28(6):543-544. https://doi.org/10.1016/j. ijantimicag.2006.07.028

Akiba M, Lin J, Barton YW, Zhang Q (2006) Interaction of CmeABC and $\mathrm{CmeDEF}$ in conferring antimicrobial resistance and maintaining cell viability in Campylobacter jejuni. J Antimicrob Chemother 57:5260. https://doi.org/10.1093/jac/dki419

Aoyama Y, Horiuchi T, Gotoh O, Noshiro M, Yoshida Y (1998) CYP51like gene of Mycobacterium tuberculosis actually encodes a P450 similar to eukaryotic CYP51. J Biochem 124(4):694-696

Ates LS, Ummels R, Commandeur S, van de Weerd R, Sparrius M, Weerdenburg E, Alber M, Kalscheuer R, Piersma SR, Abdallah AM, Abd El Ghany M, Abdel-Haleem AM, Pain A, Jiménez CR, Bitter W, Houben EN (2015) Essential role of the ESX-5 secretion system in outer membrane permeability of pathogenic mycobacteria. PLoS Genet 11:e1005190. https://doi.org/10.1371/ journal.pgen.1005190

Bacon J, James BW, Wernisch L, Williams A, Morley KA, Hatch GJ, Mangan JA, Hinds J, Stoker NG, Butcher PD, Marsh PD (2004) The influence of reduced oxygen availability on pathogenicity and gene expression in Mycobacterium tuberculosis. Tuberculosis 84(3-4): 205-217. https://doi.org/10.1016/j.tube.2003.12.011

Belin P, Le Du MH, Fielding A, Lequin O, Jacquet M, Charbonnier JB, Lecoq A, Thai R, Courçon M, Masson C, Dugave C, Genet R, Perdonet JL, Gondry M (2009) Identification and structural basis of the reaction catalyzed by CYP121, an essential cytochrome P450 in Mycobacterium tuberculosis. Proc Natl Acad Sci U S A 106(18):7426-7431. https://doi.org/10.1073/pnas.0812191106

Bellamine A, Mangla AT, Nes WD, Waterman MR (1999) Characterization and catalytic properties of the sterol $14 \alpha-$ demethylase from Mycobacterium tuberculosis. Proc Natl Acad Sci U S A 96(16):8937-8942. https://doi.org/10.1073/pnas.96.16. 8937

Betts JC, Lukey PT, Robb LC, McAdam RA, Duncan K (2002) Evaluation of a nutrient starvation model of Mycobacterium tuberculosis persistence by gene and protein expression profiling. Mol Microbiol 43(3):717-731. https://doi.org/10.1046/j.1365-2958. 2002.02779.x

Boot M, Commandeur S, Subudhi AK, Bahira M, Smith TC 2nd, Abdallah AM, van Gemert M, Lelièvre J, Ballell L, Aldridge BB, Pain A, Speer A, Bitter W (2018) Accelerating early antituberculosis drug discovery by creating mycobacterial indicator strains that predict mode of action. Antimicrob Agents Chemother 62(7):e00083e00018. https://doi.org/10.1128/AAC.00083-18

Bottai D, Di Luca M, Majlessi L, Frigui W, Simeone R, Sayes F, Bitter W, Brennan MJ, Leclerc C, Batoni G, Campa M, Brosch R, Esin S (2012) Disruption of the ESX-5 system of Mycobacterium tuberculosis causes loss of PPE protein secretion, reduction of cell wall integrity and strong attenuation. Mol Microbiol 83:1195-1209. https://doi.org/10.1111/j.1365-2958.2012.08001.x

Brengel C, Thomann A, Schifrin A, Eberhard J, Hartmann RW (2016) Discovery and biophysical evaluation of first low Nanomolar hits targeting CYP125 of Mycobacterium tuberculosis. ChemMedChem 11(21):2385-2391. https://doi.org/10.1002/cmdc.201600361

Burian J, Ramón-García S, Howes CG, Thompson CJ (2012) WhiB7, a transcriptional activator that coordinates physiology with intrinsic drug resistance in Mycobacterium tuberculosis. Expert Rev AntiInfect Ther 10(9):1037-1047. https://doi.org/10.1586/eri.12.90

Burian J, Yim G, Hsing M, Axerio-Cilies P, Cherkasov A, Spiegelman GB, Thompson CJ (2013) The mycobacterial antibiotic resistance determinant WhiB7 acts asa transcriptional activator by binding the primary sigma factor SigA (RpoV). Nucleic Acids Res 41(22): 10062-10076. https://doi.org/10.1093/nar/gkt751

Buriankova K, Doucet-Populaire F, Dorson O, Gondran A, Ghnassia JC, Weiser J, Pernodet JL (2004) Molecular basis of intrinsic macrolide resistance in the Mycobacterium tuberculosis complex. Antimicrob Agents Chemother 48:143-150. https://doi.org/10.1128/AAC.48.1. 143-150.2004

Cagliero C, Mouline C, Payot S, Cloeckaert A (2005) Involvement of the CmeABC efflux pump in the macrolide resistance of Campylobacter coli. J Antimicrob Chemother 56:948-950. https:// doi.org/10.1093/jac/dki292

Capyk JK, Kalscheuer R, Stewart GR, Liu J, Kwon H, Zhao R, Okamoto S, Jacobs WR Jr, Eltis LD, Mohn WW (2009) Mycobacterial cytochrome p450 125 (cyp125) catalyzes the terminal hydroxylation of c27 steroids. J Biol Chem 284(51):35534-35542. https://doi.org/10. 1074/jbc.M109.072132

Chang JC, Harik NS, Liao RP, Sherman DR (2007) Identification of mycobacterial genes that alter growth and pathology in 
macrophages and in mice. J Infect Dis 196(5):788-795. https://doi. org/10.1086/520089

Chang JC, Miner MD, Pandey AK, Gill WP, Harik NS, Sassetti CM, Sherman DR (2009) Igr genes and Mycobacterium tuberculosis cholesterol metabolism. J Bacteriol 191(16):5232-5239. https://doi.org/ 10.1128/JB.00452-09

Chen CK, Doyle PS, Yermalitskaya LV, Mackey ZB, Ang KK, McKerrow JH, Podust LM (2009) Trypanosoma cruzi CYP51 inhibitor derived from a Mycobacterium tuberculosis screen hit. PLoS Negl Trop Dis 3(2):e372. https://doi.org/10.1371/journal.pntd. 0000372

Chen CK, Leung SSF, Guilbert C, Jacobson MP, Mckerrow JH, Podust LM (2010) Structural characterization of CYP51 from Trypanosoma cruzi and Trypanosoma brucei bound to the antifungal drugs posaconazole and fluconazole. PLoS Negl Trop Dis 4:e651. https://doi.org/10.1371/journal.pntd.0000651

Chiaradia L, Lefebvre C, Parra J, Marcoux J, Burlet-Schiltz O, Etienne G, Tropis M, Daffé M (2017) Dissecting the mycobacterial cell envelope and defining the composition of the native mycomembrane. Sci Rep 7(1):12807. https://doi.org/10.1038/s41598-017-12718-4

Child SA, Bradley JM, Pukala TL, Svistunenko DA, Le Brun NE, Bell SG (2018) Electron transfer ferredoxins with unusual cluster binding motifs support secondary metabolism in many bacteria. Chem Sci 9(41):7948-7957. https://doi.org/10.1039/c8sc01286e

Cole ST, Brosch R, Parkhill J, Garnier T, Churcher C, Harris D, Gordon SV, Eiglmeier K, Gas S, Barry CE 3rd, Tekaia F, Badcock K, Basham D, Brown D, Chillingworth T, Connor R, Davies R, DevLin K, Feltwell T, Gentles S, Hamlin N, Holroyd S, Hornsby T, Jagels K, Krogh A, McLean J, Moule S, Murphy L, Oliver K, Osborne J, Quail MA, Rajandream MA, Rogers J, Rutter S, Seeger K, Skelton J, Squares R, Squares S, Sulston JE, Taylor K, Whitehead S, Barrell BG (1998) Deciphering the biology of Mycobacterium tuberculosis from the complete genome sequence. Nature 393(6685):537-544. https://doi.org/10.1038/31159

Cumming BM, Rahman MA, Lamprecht DA, Rohde KH, Saini V, Adamson JH, Russell DG, Steyn AJC (2017) Mycobacterium tuberculosis arrests host cycle at the G1/S transition to establish long term infection. PLoS Pathog 13(7):e1006490. https://doi.org/10. 1371/journal.ppat. 1006490

Davis EO, Dullaghan EM, Rand L (2002) Definition of the mycobacterial SOS box and use to identify LexA-regulated genes in Mycobacterium tuberculosis. J Bacteriol 184(12):3287-3295. https://doi.org/10.1128/JB.184.12.3287-3295.2002

De Rossi E, Arrigo P, Bellinzoni M, Silva PA, Martin C, Ainsa JA, Guglierame P, Riccardi G (2002) The multidrug transporters belonging to major facilitator superfamily in Mycobacterium tuberculosis. Mol Med 8:714-724

DeJesus MA, Gerrick ER, Xu W, Park SW, Long JE, Boutte CC, Rubin EJ, Schnappinger D, Ehrt S, Fortune SM, Sassetti CM, Ioerger TR (2017) Comprehensive essentiality analysis of the Mycobacterium tuberculosis genome via saturating transposon mutagenesis. $\mathrm{mBio}$ 8:e02133-e02116. https://doi.org/10.1128/mBio.02133-16

Denkin S, Byrne S, Jie C, Zhang Y (2005) Gene expression profiling analysis of Mycobacterium tuberculosis genes in response to salicylate. Arch Microbiol 184(3):152-157. https://doi.org/10.1007/ s00203-005-0037-9

Driscoll MD, Mclean KJ, Levy C, Mast N, Pikuleva IA, Lafite P, Rigby ESJ, Leys D, Munro AW (2010) Structural and biochemical characterization of Mycobacterium tuberculosis CYP142 evidence for multiple cholesterol 27-hydroxylase activities in a human. J Biol Chem 285(49):38270-38282. https://doi.org/10.1074/jbc.M110. 164293

Dubey VS, Sirakova TD, Cynamon MH, Kolattukudy PE (2003) Biochemical Function of ms15 (pks8plus pks17) in Mycobacterium tuberculosis H37Rv: Biosynthesis of Monomethyl Branched
Unsaturated Fatty Acids. J Bacteriol. 185(15):4620-4625. https:// doi.org/10.1128/JB.185.15.4620-4625.2003

Duff JLC, Breton JLJ, Butt JN, Armstrong FA, Thomson AJ (1996) Novel redox chemistry of [3Fe-4S] clusters: electrochemical characterization of the all-Fe (II) form of the [3Fe-4S] cluster generated reversibly in various proteins and its spectroscopic investigation in Sulfolobus acidocaldarius ferredoxin. J Am Chem Soc 118(36): 8593-8603. https://doi.org/10.1021/ja9614651

Dunford AJ, McLean KJ, Sabri M, Seward HE, Heyes DJ, Scrutton NS, Munro AW (2007) Rapid P450 heme iron reduction by laser photoexcitation of Mycobacterium tuberculosis CYP121 and CYP51B1. J Biol Chem 282(34):24816-24824. https://doi.org/10.1074/jbc. M702958200

Dutta NK, Mehra S, Didier PJ, Roy CJ, Doyle LA, Alvarez X, Ratterree M, Be NA, Lamichhane G, Jain SK, Lacey MR, Lackner AA, Kaushal D (2010) Genetic requirements for the survival of tubercle bacilli in primates. J Infect Dis 201(11):1743-1752. https://doi.org/ $10.1086 / 652497$

Elliott SR, Tischler AD (2016) Phosphate starvation: a novel signal that triggers ESX-5 secretion in Mycobacterium tuberculosis. Mol Microbiol 100:510-526. https://doi.org/10.1111/mmi.13332

Ewen KM, Hannemann F, Khatri Y, Perlova O, Kappl R, Krug D, Hütterman J, Müller R, Bernhardt R (2009) Genome mining in Sorangium cellulosum so ce56: Indentification characterization of the homologous electron transfer proteins of a Myxobacterial cytochrome P450. J Biol Chem 284(42):28590-28598. https://doi.org/ 10.1074/jbc.M109.021717

Fang H, Yu D, Hong Y, Zhou X, Li C, Sun B (2013) The LuxR family regulator Rv0195 modulates Mycobacterium tuberculosis dormancy and virulence. Tuberculosis 93(4):425-431. https://doi.org/10.1016/ j.tube.2013.04.005

Fischer F, Raimondi D, Aliverti A, Zanetti G (2002) Mycobacterium tuberculosis FprA, a novel bacterial NADPH-ferredoxin reductase. Eur J Biochem 269:3005-3013. https://doi.org/10.1046/j.14321033.2002.02989.x

Fisher MA, Plikaytis BB, Shinnick TM (2002) Microarray analysis of the Mycobacterium tuberculosis transcriptional response to the acidic conditions found in phagosomes. J Bacteriol 184(14):4025-4032. https://doi.org/10.1128/JB.184.14.4025-4032.2002

Fonvielle M, Le Du MH, Lequin O, Lecoq A, Jacquet M, Thai R, Dubois S, Grach G, Gondry M, Belin P (2013) Substrate and reaction specificity of Mycobacterium tuberculosis cytochrome P450 CYP121: insights from biochemical studies and crystal structures. J Biol Chem 288(24):17347-17359. https://doi.org/10.1074/jbc.M112. 443853

Frank DJ, Zhao Y, Wong SH, Basudhar D, De Voss JJ, Ortiz de Montellano PR (2016) Cholesterol analogs with degradationresistant alkyl side chains are effective Mycobacterium tuberculosis growth inhibitors. J Biol Chem 291(14):7325-7333. https://doi.org/ 10.1074/jbc.M115.708172

Gazaei C (2018) Mycobacterium tuberculosis and lipids: insights into molecular mechanism from persistence to virulence. J Res Med Sci 23:63. https://doi.org/10.4103/jrms.JRMS.904.17

Geiman DE, Raghunand TR, Agarwal N, Bishai WR (2006) Differential gene expression in response to exposure to antimycobacterial agents and other stress conditions among seven Mycobacterium tuberculosis whiB-like genes. Antimicrob Agents Chemother 50: 2836-2841. https://doi.org/10.1128/AAC.00295-06

Gokulan K, O'Leary SE, Russell WK, Russell DH, Lalgondar M, Begley TP, Ioerger TR, Sacchettini JC (2013) Crystal structure of Mycobacterium tuberculosis polyketide synthase 11 (PKS11) reveals intermediates in the synthesis of methyl-branched alkylpyrones. J Biol Chem 288(23):16484-16494. https://doi.org/ 10.1074/jbc.M113.468892

Green AJ, Munro AW, Cheesman MR, Reid GA, Von Wachenfeldt C, Chapman SK (2003) Expression, purification and characterisation 
of a Bacillus subtilis ferredoxin: a potential electron transfer donor to cytochrome P450. BioI J Inorg Biochem 93(1-2):92-99. https://doi. org/10.1016/s0162-0134(02)00456-7

Griffin JE, Gawronski JD, DeJesus MA, Ioerger TR, Akerley BJ, Sassetti CM (2011) Phenotypic profiling defines genes essential for mycobacterial growth and cholesterol catabolism. PLoS Pathog 7(9): e1002251. https://doi.org/10.1371/journal.ppat.1002251

Guardiola-Diaz HM, Foster LA, Mushrush D, Vaz AD (2001) Azoleantifungal binding to a novel cytochrome $\mathrm{P} 450$ from Mycobacterium tuberculosis: implications for treatment of tuberculosis. Biochem Pharmacol 61:1463-1470. https://doi.org/10.1016/ S0006-2952(01)00571-8

Guazzaroni ME, Krell T, Felipe A, Ruiz R, Meng C, Zhang X, Gallegos MT, Ramos JL (2005) The multidrug efflux regulator TtgV recognizes a wide range of structurally different effectors in solution and complexed with target DNA: evidence from isothermal titration calorimetry. J Biol Chem 280:20887-20893. https://doi.org/10.1074/ jbc.M500783200

Hampshire T, Soneji S, Bacon J, James BW, Hinds J, Laing K, Stabler RA, Marsh PD, Butcher PD (2004) Stationary phase gene expression of Mycobacterium tuberculosis following a progressive nutrient depletion: a model for persistent organisms? Tuberculosis 84(3-4): 228-238. https://doi.org/10.1016/j.tube.2003.12.010

Holsclaw CM, Sogi KM, Gilmore SA, Schelle MW, Leavell MD, Bertozzi CR, Leary JA (2008) Structural characterization of a novel sulfated menaquinone produced by stf3 from Mycobacterium tuberculosis. ACS Chem Biol 3(10):619-624. https://doi.org/10. 1021/cb800145r

Hudson SA, McLean KJ, Surade S, Yang YQ, Leys D, Ciulli A, Munro AW, Abell C (2012) Application of fragment screening and merging to the discovery of inhibitors of the Mycobacterium tuberculosis cytochrome P450 CYP121. Angew Chem Int Ed Eng 51(37): 9311-9316. https://doi.org/10.1002/anie.201202544

Hudson SA, Surade S, Coyne AG, McLean KJ, Leys D, Munro AW, Abell C (2013) Overcoming the limitations of fragment merging: rescuing a strained merged fragment series targeting Mycobacterium tuberculosis CYP121. ChemMedChem 8(9):1451-1456. https://doi. org/10.1002/cmdc.201300219

Hudson SA, Mashalidis EH, Bender A, McLean KJ, Munro AW, Abell C (2014) Biofragments: an approach towards predicting protein function using biologically related fragments and its application to Mycobacterium tuberculosis CYP126. Chembiochem 15(4):549 555. https://doi.org/10.1002/cbic.201300697

Jackson M (2014) The mycobacterial cell envelope-lipids. Cold Spring Harb Perspect Med 4(10):a021105. https://doi.org/10.1101/ cshperspect.a021105

Jain SK, Hernandez-Abanto SM, Cheng QJ, Singh P, Ly LH, Klinkenberg LG, Morrison NE, Converse PJ, Nuermberger E, Grosset J, McMurray DN, Karakousis PC, Lamichhane G, Bishai WR (2007) Accelerated detection of Mycobacterium tuberculosis genes essential for bacterial survival in Guinea pigs, compared with mice. J Infect Dis 195(11):1634-1642. https://doi.org/10.1086/ 517526

Jiang X, Zhang W, Zhang Y, Gao F, Lu C, Zhang X, Wang H (2008) Assessment of efflux pump gene expression in a clinical isolate Mycobacterium tuberculosis by real-time reverse transcription PCR. Microb Drug Resist 14(1):7-11. https://doi.org/10.1089/mdr. 2008.0772

Johnston JB, Kells PM, Podust LM, Ortiz de Montellano PR (2009) Biochemical and structural characterization of CYP124: a methylbranched lipid omega-hydroxylase from Mycobacterium tuberculosis. Proc Natl Acad Sci U S A 106(49):20687-20692. https://doi.org/10.1073/pnas.0907398106

Johnston JB, Ouellet H, Ortiz de Montellano PR (2010) Functional redundancy of steroid C26-monooxygenase activity in Mycobacterium tuberculosis revealed by biochemical and genetic analysis. J Biol Chem 285:36352-36360. https://doi.org/10.1074/ jbc.M110.161117

Kavanagh ME, Coyne AG, McLean KJ, James GG, Levy CW, Marino LB, de Carvalho LP, Chan DS, Hudson SA, Surade S, Leys D, Munro AW, Abell C (2016) Fragment-based approaches to the development of Mycobacterium tuberculosis CYP121 inhibitors. J Med Chem 59(7):3272-3302. https://doi.org/10.1021/acs. jmedchem.6b00007

Kim D, Guengerich FP (2005) Cytochrome P450 activation of arylamines and heterocyclic amines. Annu Rev Pharmacol Toxicol 45:27-49. https://doi.org/10.1146/annurev.pharmtox.45.120403. 100010

Koul A, Vranckx L, Dhar N, Göhlmann HW, Özdemir E, Neefs JM, Schulz M, Lu P, Mørtz E, McKinney JD, Andries K, Bald D (2014) Delayed bactericidal response of Mycobacterium tuberculosis to bedaquiline involves remodelling of bacterial metabolism. Nat Commun 5:3369. https://doi.org/10.1038/ncomms4369

Kumar M, Khan FG, Sharma S, Kumar R, Faujdar J, Sharma R, Chauhan DS, Singh R, Magotra SK, Khan IA (2011) Identification of Mycobacterium tuberculosis genes preferentially expressed during human infection. Microb Pathog 50(1):31-38. https://doi.org/10. 1016/j.micpath.2010.10.003

Lamichhane G, Zignol M, Blades NJ, Gelman DE, Dougherty A, Grosset J, Broman KW, Bishai WR (2003) A postgenomic method for predicting essential genes at subsaturation levels of mutagenesis: application to Mycobacterium tuberculosis. Proc Natl Acad Sci U S A 100(12):7213-7218. https://doi.org/10.1073/pnas.1231432100

Lamichhane G, Tyagi S, Bishai WR (2005) Designer arrays for defined mutant analysis to detect genes essential for survival of Mycobacterium tuberculosis in mouse lungs. Infect Immun 73(4): 2533-2540. https://doi.org/10.1128/IAI.73.4.2533-2540.2005

Lee W, VanderVen BC, Fahey RJ, Russell DG (2013) Intracellular Mycobacterium tuberculosis exploits host derived fatty acids to limit metabolic stress. J Biol Chem 288(10):6788-6800. https://doi.org/ 10.1074/jbc.M112.445056

Lenaerts A, Barry CE, Dartroits V (2015) Heterogeneity in tuberculosis pathology, microenvironments and therapeutic responses. Immunol Rev 264(1):288-307. https://doi.org/10.1111/imr.12252

Lepesheva GI, Hargrove TY, Kleshchenko Y, Nes WD, Villalta F, Waterman MR (2008) CYP51: a major drug target in the cytochrome P450 superfamily. Lipids 43:1117-1125. https://doi.org/ 10.1007/s11745-008-3225-y

Lin J, Akiba M, Sahin O, Zhang Q (2005) CmeR functions as a transcriptional repressor for the multidrug efflux pump CmeABC in Campylobacter jejuni. Antimicrob Agents Chemother 49:10671075. https://doi.org/10.1128/AAC.49.3.1067-1075.2005

Little JW (1991) Mechanism of specific LexA cleavage: autodigestion and the role of RecA coprotease. Biochimie 73(4):411-421. https:// doi.org/10.1016/0300-9084(91)90108-D

Lu Y, Qiao F, Li Y, Sang XH, Li CR, Jiang JD, Yang XY, You XF (2017) Recombinant expression and biochemical characterization of Mycobacterium tuberculosis 3Fe-4S ferredoxin Rv1786. Appl Microbiol Biotechnol 101(19):7201-7212. https://doi.org/10.1007/ s00253-017-8454-7

McKinney JD, Höner zu Bentrup K, Muñoz-Elías EJ, Miczak A, Chen B, Chan WT, Swenson D, Sacchettini JC, Jacobs WR Jr, Russell DG (2000) Persistence of Mycobacterium tuberculosis in macrophages and mice requires the glyoxylate shunt enzyme isocitrate lyase. Nature 406:735-738. https://doi.org/10.1038/35021074

McLean MJ, Munro AW (2008) Structural biology and biochemistry of cytochrome P450 systems in Mycobacterium tuberculosis. Drug Metab Rev 40(3):427-446. https://doi.org/10.1080/ 03602530802186389

McLean KJ, Cheesman MR, Rivers SL, Richmond A, Leys D, Chapman SK, Reid GA, Price NC, Kelly SM, Clarkson J, Smith WE, Munro AW (2002a) Expression, purification and spectroscopic 
characterization of the cytochrome P450 CYP121 from Mycobacterium tuberculosis. J Inorg Biochem 91(4):527-541. https://doi.org/10.1016/S0162-0134(02)00479-8

McLean KJ, Marshall KR, Richmond A, Hunter IS, Fowler K, Kieser T, Gurcha SS, Besra GS, Munro AW (2002b) Azole antifungals are potent inhibitors of cytochrome $\mathrm{P} 450$ mono-oxygenases and bacterial growth in mycobacteria and streptomycetes. Microbiology 148(Pt 10):2937-2949. https://doi.org/10.1099/00221287-148-102937

McLean KJ, Sabri M, Marshall KR, Lawson RJ, Lewis DG, Clift D, Baldin PR, Dunford AJ, Warman AJ, McVey JP, Quinn AM, Sutcliffe MJ, Scrutton NS, Munro AW (2005) Biodiversity of cytochrome P450 redox systems. Biochem Soc Trans 33(Pt4):796-801. https://doi.org/10.1042/BST0330796

McLean KJ, Warman AJ, Seward HE, Marshall KR, Girvan HM, Cheesman MR, Waterman MR, Munro AW (2006a) Biophysical characterization of the sterol demethylase P450 from Mycobacterium tuberculosis, its cognate ferredoxin, and their interactions. Biochemistry 45(27):8427-8443. https://doi.org/10.1021/ bi0601609

McLean KJ, Clift D, Lewis DG, Sabri M, Balding PR, Sutcliffe MJ, Leys D, Munro AW (2006b) The preponderance of P450s in the Mycobacterium tuberculosis genome. Trends Microbiol 14(5): 220-228. https://doi.org/10.1016/j.tim.2006.03.002

McLean KJ, Dunford AJ, Neeli R, Driscoll MD, Munro AW (2007) Structure, function and drug targeting in Mycobacterium tuberculosis cytochrome P450 systems. Arch Biochem Biophys 464:228-240. https://doi.org/10.1016/j.abb.2007.03.026

McLean KJ, Carroll P, Lewis DG, Dunford AJ, Seward HE, Neeli R, Chesman LM, Douglas P, Smith WE, Rosenkrands I, Cole ST, Munro AW (2008) Characterization of active site structure in CYP121: a cytochrome P450 essential for viability of Mycobacterium tuberculosis H37Rv. J Biol Chem 283(48):3340633416. https://doi.org/10.1074/jbc.M802115200

McLean KJ, Lafite P, Levy C, Cheesman MR, Mast N, Pikuleva IA, Leys D, Munro AW (2009) The structure of Mycobacterium tuberculosis CYP125: molecular basis for cholesterol binding in a P450 needed for host infection. J Biol Chem 284:35524-35533. https://doi.org/ 10.1074/jbc.M109.032706

McLean KJ, Belcher J, Driscoll MD, Fernandez CC, Le Van D, Bui S, Golovanova M, Munro AW (2010) The Mycobacterium tuberculosis cytochromes P450: physiology, biochemistry \& molecular intervention. Future Med Chem 2(8):1339-1353. https://doi. org/10.4155/fmc. 10.216

Morris RP, Nguyen L, Gatfield J, Visconti K, Nguyen K, Schnappinger D, Ehrt S, Liu Y, Heifets L, Pieters J, Schoolnik G, Thompson CJ (2005) Ancestral antibiotic resistance in Mycobacterium tuberculosis. Proc Natl Acad Sci U S A 102(34):12200-12205. https://doi.org/10.1073/pnas.0505446102

Mougous JD, Senaratne RH, Petzold CJ, Jain M, Lee DH, Schelle MW, Leavell MD, Cox JS, Leary JA, Riley LW, Bertozzi CR (2006) A sulfated metabolite produced by stf3 negatively regulates the virulence of Mycobacterium tuberculosis. Proc Natl Acad Sci U S A 103(11):4258-4263. https://doi.org/10.1073/pnas.0510861103

Namouchi A, Gómez-Muñoz M, Frye SA, Moen LV, Rognes T, Tønjum T, Balasingham SV (2016) The Mycobacterium tuberculosis transcriptional landscape under genotoxic stress. BMC Genomics 17(1): 791. https://doi.org/10.1186/s12864-016-3132-1

Nikaido H, Jarlier V (1991) Permeability of the mycobacterial cell wall. Res Microbiol 142(4):437-443. https://doi.org/10.1016/09232508(91) $90117-\mathrm{S}$

Nishioka WK, Welsh RM (1994) Susceptibility to cytotoxic T lymphocyte-induced apoptosis is a function of the proliferative status of the target. J Exp Med 179(2):769-774. https://doi.org/10. 1084/jem.179.2.769
Ortega Ugalde S, de Koning CP, Wallraven K, Bruyneel B, Vermeulen NPE, Grossmann TN, Bitter W, Commandeur JNM, Vos JC (2018a) Linking cytochrome P450 enzymes from Mycobacterium tuberculosis to their cognate ferredoxin partners. Appl Microbiol Biotechnol 102:9231-9242. https://doi.org/10.1007/s00253-0189299-4

Ortega Ugalde S, Luirink RA, Geerke DP, Vermeulen NPE, Bitter W, Commandeur JNM (2018b) Engineering a self-sufficient Mycobacterium tuberculosis CYP130 by gene fusion with the reductase-domain of CYP102A1 from Bacillus megaterium. J Inorg Biochem 180:47-53. https://doi.org/10.1016/j.jinorgbio. 2017.12.003

Ortiz de Montellano PR (2018) Potential drug targets in the Mycobacterium tuberculosis cytochrome P450 system. J Inorg Biochem 180:235-245. https://doi.org/10.1016/j.jinorgbio.2018. 01.010

Ouellet H, Johnston JB, Ortiz de Montellano PR (2010a) The Mycobacterium tuberculosis cytochrome P450 system. Arch Biochem Biophys 493(1):82-95. https://doi.org/10.1016/j.abb. 2009.07.011

Ouellet H, Guan S, Johnston JB, Chow ED, Kells PM, Burlingame AL, Cox JS, Podust LM, Ortiz de Montellano PR (2010b) Mycobacterium tuberculosis CYP125A1, a steroid C27 monooxygenase that detoxifies intracellularly generated cholest-4en-3-one. Mol Microbiol 77(3):730-742. https://doi.org/10.1111/j. 1365-2958.2010.07243.x

Ouellet H, Kells PM, Ortiz de Montellano PR, Podust LM (2011) Reverse type I inhibitor of Mycobacterium tuberculosis CYP125A1. Bioorg Med Chem Lett 21(1):332-337. https://doi.org/10.1016/j.bmcl. 2010.11.007

Park DK, Lee KE, Baek CH, Kim IH, Kwon JH, Lee WK, Lee KH, Kim BS, Choi SH, Kim KS (2006) Cyclo(Phe-pro) modulates the expression of ompU in Vibrio spp. J Bacteriol 188(6):2214-2221. https:// doi.org/10.1128/JB.188.6.2214-2221.2006

Parvez M, Qhanya LB, Mthakathi NT, Kgosiemang IK, Bamal HD, Pagadala NS, Xie T, Yang H, Chen H, Theron CW, Monyaki R, Raselemane SC, Salewe V, Mongale BL, Matowane RG, Abdalla SM, Booi WI, van Wyk M, Olivier D, Boucher CE, Nelson DR, Tuszynski JA, Blackburn JM, Yu JH, Mashele SS, Chen W, Syed K (2016) Molecular evolutionary dynamics of cytochrome P450 monooxygenases across kingdoms: special focus on mycobacterial P450s. Sci Rep 6:33099. https://doi.org/10.1038/srep33099

Peterson EJR, Ma S, Sherman DR, Baliga NS (2016) Network analysis identifies Rv0324 and Rv0880 as regulators of bedaquiline tolerance in Mycobacterium tuberculosis. Nat Microbiol 1(8):16078. https:// doi.org/10.1038/nmicrobiol.2016.78

Pisu D, Provvedi R, Espinosa DM, Payan JB, Boldrin F, Palù G, Hernandez-Pando R, Manganelli R (2017) The alternative sigma factors SigE and SigB are involved in tolerance and persistence to antitubercular drugs. Antimicrob Agents Chemother 61(12). https:// doi.org/10.1128/AAC.01596-17

Podust LM, Poulos TL, Waterman MR (2001) Crystal structure of cytochrome P450 14 $\alpha$-sterol demethylase (CYP51) from Mycobacterium tuberculosis in complex with azole inhibitors. Proc Natl Acad Sci U S A 98(6):3068-3073. https://doi.org/10. 1073/pnas.061562898

Podust LM, Yermalitskaya LV, Lepesheva GI, Podust VN, Dalmasso EA, Waterman MR (2004) Estriol bound and ligand-free structures of sterol 14alpha-demethylase. Structure 12(11):1937-1945. https:// doi.org/10.1016/j.str.2004.08.009

Podust LM, Ouellet H, von Kries JP, Ortiz de Montellano PR (2009) Interaction of Mycobacterium tuberculosis CYP130 with heterocyclic Arylamines. J Biol Chem 284(37):25211-25219. https://doi. org/10.1074/jbc.M109.01763

Rengarajan J, Bloom BR, Rubin EJ (2005) Genome-wide requirements for Mycobacterium tuberculosis adaptation and survival in 
macrophages. Proc Natl Acad Sci U S A 102(23):8327-8332. https://doi.org/10.1073/pnas.0503272102

Ricagno S, De Rosa M, Aliverti A, Zanetti G, Bolognesi M (2007) The crystal structure of FdxA, a 7Fe ferredoxin from Mycobacterium smegmatis. Biochem Biophys Res Commun 360(1):97-102. https://doi.org/10.1016/j.bbrc.2007.06.013

Riccardi G, Pasca MR (2014) Trends in discovery of new drugs for tuberculosis therapy. J Antibiot 67(9):655-659. https://doi.org/10. 1038/ja.2014.109

Rimal H, Lee SW, Lee JH, Oh TJ (2015) Understanding of real alternative redox partner of Streptomyces peucetius DoxA: prediction and validation using in silico and in vitro analyses. Arch Biochem Biophys 585:64-74. https://doi.org/10.1016/j.abb.2015.08.019

Rustad TR, Minch KJ, Ma S, Winkler JK, Hobbs S, Hickey M, Brabant W, Turkarslan S, Price ND, Baliga NS, Sherman DR (2014) Mapping and manipulating the Mycobacterium tuberculosis transcriptome using a transcription factor overexpression-derived regulatory network. Genome Biol 15(11):502. https://doi.org/10.1186/ PREACCEPT-1701638048134699

Sassetti CM, Rubin EJ (2003) Genetic requirements for mycobacterial survival during infection. Proc Natl Acad Sci U S A 100(22):1298912994. https://doi.org/10.1073/pnas.2134250100

Sassetti CM, Boyd DH, Rubin EJ (2003) Genes required for microbial growth in defined high density mutagenesis. Mol Microbiol 48(1): 77-84. https://doi.org/10.1046/j.1365-2958.2003.03425.x

Saxena P, Yadav G, Mohanty D, Gokhale RS (2003) A new family of type III polyketide synthases in Mycobacterium tuberculosis. J Biol Chem 278:44780-44790. https://doi.org/10.1074/jbc.M306714200

Sayes F, Sun L, Di Luca M, Simeone R, Degaiffier N, Fiette L, Esin S, Brosch R, Bottai D, Leclerc C, Majlessi L (2012) Strong immunogenicity and cross-reactivity of Mycobacterium tuberculosis ESX-5 type VII secretion: encoded PE-PPE proteins predicts vaccine potential. Cell Host Microbe 11:352-363. https://doi.org/10.1016/j. chom.2012.03.003

Schnappinger D, Ehrt S, Voskuil MI, Liu Y, Mangan JA, Monahan IM, Dolganov G, Efron B, Butcher PD, Nathan C, Schoolnik GK (2003) Transcriptional adaptation of Mycobacterium tuberculosis within macrophages: insights into the phagosomal environment. J Exp Med 198(5):693-704. https://doi.org/10.1084/jem.20030846

Sevrioukova IF (2005) Redox-dependent structural reorganization in putidaredoxin, a vertebrate-type [2Fe-2S] ferredoxin from Pseudomonas putida. J Mol Biol 347(3):607-621. https://doi.org/ 10.1016/j.jmb.2005.01.047

Seward HE, Roujeinikova A, McLean KJ, Munro AW, Leys D (2006) Crystal structure of the Mycobacterium tuberculosis P450 CYP121fluconazole complex reveals new azole drug-P450 binding mode. J Biol Chem 281(51):39437-39443. https://doi.org/10.1074/jbc. M607665200

Sherman DR, Voskuil M, Schnappinger D, Liao R, Harrell MI, Schoolnik GK (2001) Regulation of the Mycobacterium tuberculosis hypoxic response gene encoding alpha-crystallin. Proc Natl Acad Sci U S A 98(13):7534-7539. https://doi.org/10.1073/pnas.121172498

Shiloh MU, Manzanillo P, Cox JS (2008) Mycobacterium tuberculosis senses host-derived carbon monoxide during macrophage infection. Cell Host Microbe 3(5):323-330. https://doi.org/10.1016/j.chom.2008.03.007

Siddiqi N, Das R, Pathak N, Banerjee S, Ahmed N, Katoch VM, Hasnain SE (2004) Mycobacterium tuberculosis isolate with a distinct genomic identity overexpresses a tap-like efflux pump. Infection 32(2): 109-111. https://doi.org/10.1007/s15010-004-3097-x

Stewart GR, Wernisch L, Stabler R, Mangan JA, Hinds J, Laing KG, Young DB, Butcher PD (2002) Dissection of the heat-shock response in Mycobacterium tuberculosis using mutants and microarrays. Microbiology 148:3129-3138. https://doi.org/10.1099/ 00221287-148-10-3129

Talaat AM, Lyons R, Howard ST, Johnston SA (2004) The temporal expression profile of Mycobacterium tuberculosis infection in mice. Proc Natl Acad Sci U S A 101(13):4602-4607. https://doi.org/10. 1073/pnas.0306023101

ten Bokum AM, Movahedzadeh F, Frita R, Bancroft GJ, Stoker NG (2008) The case for hypervirulence through gene deletion in Mycobacterium tuberculosis. Trends Microbiol 16(9):436-441. https://doi.org/10.1016/j.tim.2008.06.003

Trower MK, Lenstra R, Omer C, Buchholz SE, Sariaslani FS (1993) Cloning, nucleotide sequence determination and expression of the genes encoding cytochrome P450soy (soyC) and ferredoxin soy (soyB) from Streptomyces griseus. Mol Microbiol 7(6):10241025. https://doi.org/10.1111/j.1365-2958.1992.tb01386.x

VanderVen BC, Fahey RJ, Lee W, Liu Y, Abramovitch RB, Memmott C, Crowe AM, Eltis LD, Perola E, Deininger DD, Wang T, Locher CP, Russell DG (2015) Novel inhibitors of cholesterol degradation in Mycobacterium tuberculosis reveal how the bacterium's metabolism is constrained by the intracellular environment. PLoS Pathog 11(2): e1004679. https://doi.org/10.1371/journal.ppat.1004679

Voskuil ML, Visconti KC, Schoolnik GK (2004) Mycobacterium tuberculosis gene expression during adaptation to stationary phase and low-oxygen dormancy. Tuberculosis 84:218-227. https://doi. org/10.1016/j.tube.2004.02.003

Warrilow AG, Parker JE, Kelly DE, Kelly SL (2013) Azole affinity of sterol 14alpha-demethylase (CYP51) enzymes from Candida albicans and Homo sapiens. Antimicrob Agents Chemother 57(3): 1352-1360. https://doi.org/10.1128/AAC.02067-12

Weerdenburg EM, Abdallah AM, Rangkuti F, Abd El Ghany M, Otto TD, Adroub SA, Molenaar D, Ummels R, ter Veen K, van Stempvoort G, van der Sar AM, Ali S, Langridge GC, Thomson NR, Pain A, Bitter W (2015) Genome-wide transposon mutagenesis indicates that Mycobacterium marinum customizes its virulence mechanisms for survival and replication in different hosts. Infect Immun 83: 1778-1788. https://doi.org/10.1128/IAI.03050-14

Wilburn KM, Fieweger RA, VanderVen BC (2018) Cholesterol and fatty acids grease the wheels of Mycobacterium tuberculosis pathogenesis. Pathog Dis 76(2). https://doi.org/10.1093/femspd/fty021

World Health Organization, 2018. Global tuberculosis report 2018. World Health Organization, Geneva. http://apps.who.int/iris/bitstream/ handle/10665/274453/9789241565646-eng.pdf?ua=1. Accessed 29 Nov 2018

Xu G, Ni Z, Shi Y, Sun X, Wang H, Wei C, Wang G, Li F (2014) Screening essential genes of Mycobacterium tuberculosis with the pathway enrichment method. Mol Biol Rep 41(11):7639-7644. https://doi.org/10.1007/s11033-014-3654-Z

Zanno A, Kwiatkowski N, Vaz ADN, Guardiola-Diaz HM (2005) MT FdR: a ferredoxin reductase from Mycobacterium tuberculosis that couples to MT CYP51. Biochim Biophys Acta Bioenerg 1707:157169. https://doi.org/10.1016/j.bbabio.2004.11.010

Zhang YJ, Ioerger TR, Huttenhower C, Long JE, Sassetti CM, Sacchettini JC, Rubin EJ (2012) Global assessment of genomic regions required for growth in Mycobacterium tuberculosis. PLoS Pathog 8(9): e1002946. https://doi.org/10.1371/journal.ppat.1002946

Zhang Y, Zhang J, Cui P, Zhang Y, Zhang W (2017) Identification of novel efflux proteins Rv0191, Rv3756c, Rv3008, and Rv1667c involved in pyrazinamide resistance in Mycobacterium tuberculosis. Antimicrob Agents Chemother 61(8):e00940-e00917. https://doi. org/10.1128/AAC.00940-17 